\title{
Apartheid brasileiro: \\ raça e segregação residencial no Rio de Janeiro ${ }^{1}$
}

\author{
João H. Costa Vargas \\ Center for African and African American Studies \\ Department of Anthropology - University of Texas
}

RESUMO: Neste artigo descrevo os eventos políticos principais que, em julho de 2001, levaram à instalação de portões e câmeras em volta do Jacarezinho, a segunda maior favela do Rio de Janeiro, e as imediatas reações negativas a essas medidas na imprensa - especialmente jornais e redes de TV. Analiso essas reaçôes a partir de dados etnográficos que tenho coletado desde junho de 2001 no Rio de Janeiro, quando iniciei um trabalho de colaboração com ativistas negras/os que, com a ajuda de ex-membros do grupo Panteras Negras (EUA), ousaram desafiar a polícia, os traficantes de drogas e, de fato, setores mais amplos da sociedade. Através da análise da cobertura dos jornais sobre o "condomínio-favela" e dos debates públicos que se seguiram, demonstro como tais discursos, ainda que de forma freqüentemente tácita, desumanizam negras/os ao associá-las/os ao crime, à corrupção e às favelas - bairros das classes trabalhadoras considerados como o local onde futuras geraçóes de negras/os perigosas/os continuarão a aterrorizar a imaginação e a vida daquelas pessoas que não moram em favelas. Concluo o artigo com uma avaliação da literatura acadêmica sobre cidades brasileiras e sugiro que é necessário dar atenção às formas como raça e espaço urbano interagem se a pesquisa nessa área pretende compreender e dialogar com ativistas moradores de favelas que não têm outra saída a não ser confrontar sua contínua desumanização.

PALAVRAS-CHAVE: Brasil, Rio de Janeiro, favela, raça, espaço urbano, ativismo, alianças transnacionais. 
João H. Costa Vargas. Apartheid brasileiro...

Tudo começou com uma idéia inusitada: e se a favela fosse fechada com portōes e câmeras de segurança? Condomínios das classes média e alta em todo o Rio de Janeiro - assim como nos grandes centros urbanos no País (Caldeira, 2000; Zaluar, 1994) - são definidos com base em tais medidas de proteção. Por que então não adotar as mesmas estratégias em uma tentativa de limitar o abuso policial e o tráfico de drogas? Os ativistas que pensaram nessa idéia nem sequer se preocuparam em consultar o resto da comunidade, pois estavam certos de que os portões e as câmeras seriam aprovados por unanimidade. Assim, foram em frente e instalaram os equipamentos de segurança em pontos-chave da Favela do Jacarezinho. As câmeras, disse-me um dos membros da Associação dos Moradores, foram doadas por um "cigano que tinha ouvido falar de nosso trabalho". ${ }^{2}$ Filmadoras camcorder complementaram a estratégia para restringir o abuso policial e o comércio de drogas.

O experimento ousado teve vida curta. Ativistas locais anteciparam as reações negativas contra o condomínio-favela, e pôr a idéia em prática foi uma medida calculada para criar um fato público-político revelador das condiçôes péssimas existentes naquela comunidade pobre e marginalizada. A notícia correu rápido não apenas na cidade e no estado do Rio de Janeiro, mas também em São Paulo, onde, a despeito da violência urbana crescente, a fascinação histórica com as favelas cariocas gerou um artigo de página inteira em um dos principais jornais do País, a Folha de S.Paulo. Ainda assim, ativistas na favela ficaram surpresos com a forma visceral com que a polícia, o público que não vive em favelas e os políticos, incluindo os de esquerda, reagiram contra a idéia que viam como lunática. Nos dois maiores centros urbanos brasileiros, as questões essenciais por detrás das reaçóes ao que ocorria no Jacarezinho revelavam um profundo desconforto: como um bairro pobre, majoritariamente negro, poderia ter a ousadia de monitorar e restringir o trabalho da polícia? ${ }^{3}$ Como a diretoria de uma associação de moradores, que 
Revista de Antropologia, São Paulo, USP, 2005, v. 48 no 1.

muitos acreditavam ser controlada por traficantes de drogas, poderia desafiar aqueles que a haviam colocado no poder? Como uma favela poderia se comparar aos condomínios cercados da elite?

Neste artigo, descrevo os eventos políticos principais que, em julho de 2001, levaram à instalação de portões e câmeras em volta do Jacarezinho, a segunda maior favela do Rio de Janeiro, e as imediatas reaçóes negativas a essas medidas na imprensa - especialmente jornais e redes de TV. Analiso essas reaçóes a partir de dados etnográficos que venho coletando desde junho de 2001 no Rio de Janeiro, quando iniciei uma colaboração com ativistas negras/os que, com a ajuda de ex-membros do grupo Panteras Negras radicados em Los Angeles, nos Estados Unidos, ousaram desafiar a polícia, os traficantes de drogas e, de fato, setores mais amplos da sociedade. Através da análise da cobertura dos jornais sobre o "condomínio-favela” e dos debates públicos que se seguiram, argumento que tais discursos, ainda que de forma freqüentemente tácita, desumanizam as/os negras/os ao associá-los ao crime, à corrupção e às favelas - bairros das classes trabalhadoras considerados como os locais onde futuras gerações de negras/os perigosas/os continuarão a aterrorizar a imaginação e a vida daquelas pessoas que não moram em favelas.

Notícias não são feitas no vácuo; elas expressam idéias sobre negras/os baseadas em um senso comum hegemônico (Gordon, 1998; Hall 1980 , 1982). Utilizando-se de um idioma público para descrever grupos racializados, o noticiário dos jornais e televisionados dão voz e apoiam formas de discriminação estrutural contra negras/os que são resultado de políticas públicas e do comportamento cotidiano. Curiosamente, no entanto, as notícias sobre os conflitos políticos no Jacarezinho que apareceram no Rio e em São Paulo mostraram negras/os nas favelas mas nunca mencionaram raça. ${ }^{4}$ Ainda assim, estereótipos sobre negras/os eram articulados de maneira sub-reptícia. Quando comunidades pobres, crime, drogas e violência eram abordados, a conexão 
João H. Costa Vargas. Apartheid brasileiro...

tácita - mas sem dúvida poderosa - que se fazia era com a população negra. Esse silêncio, também presente no debate público que se seguiu, ao impedir que certas concepções sobre as/os negras/os brasileiros viessem à tona, reforçou os estereótipos e justificou a discriminação. Pleno de significado, assim, o silêncio sobre raça forma uma atmosfera na qual o racismo respira e se mantém. Ademais, o silêncio protege aquele que o produz de ser visto como alguém abertamente preconceituoso e, como quase ninguém parece ser preconceituoso, o mito brasileiro da democracia racial se mantém (Goldstein, 2003; Guimarães, 1999; Nascimento, 1989; Twine, 1998). ${ }^{5}$

As questóes que estruturam este ensaio nos ajudam a entender esse episódio no Jacarezinho, mas também fornecem ângulos pelos quais se pode analisar categorias e experiências que se reforçam mutuamente, são socialmente construídas e têm forte conotação política ao relacionarem raça e espaço urbano. Essas questões são: (1) Como noções sobre o espaço urbano brasileiro são influenciadas por concepções hegemônicas de raça? (2) Como concepções hegemônicas de raça matizam a compreensão do espaço urbano? (3) Quais são as conseqüências políticas do círculo cognitivo que existe entre raça e espaço urbano no contexto brasileiro? Essas três perguntas tentam responder à questão mais óbvia e fundamental: Por que as câmeras no Jacarezinho causaram reações tão passionais? Como este artigo irá demonstrar, havia algo mais naquela indignação do que apenas a convicção de que as câmeras e os portôes iriam dificultar o trabalho da polícia e proteger o tráfico de drogas. A indignação vinha, em grande medida, com a forma pela qual a instalação daquele equipamento no Jacarezinho desafiava as relações tácitas, freqüentemente reprimidas, mas perfeitamente claras, entre negritude e favela. Em outras palavras, o uso do equipamento de segurança rompia com a compreensão hegemônica de espaços urbanos racializados definidos a partir de atividades ilícitas e de moradores desprovidos de 
Revista de Antropologia, São Paulo, USP, 2005, v. 48 No 1.

agência política legítima. Concebidos dessa forma, moradores de favelas são, em última análise, perigosos, subumanos e incapazes de ações políticas racionais e organizadas. Favelas têm sido pensadas como áreas necessariamente permeáveis e sujeitas às regras da lei a todo e qualquer momento; como lugares onde medidas preventivas violentas sancionadas pelo Estado e pela sociedade destinam-se a conter os perigos que possuem - antes que tais perigos possam infiltrar-se no espaço político mais amplo. ${ }^{6}$

Ao simbolizar vontade política e uma crítica tanto à polícia quanto às formas injustas como a sociedade em geral opera em relação a nãobrancos e pobres, os portōes e as câmeras do Jacarezinho constituíram um desafio frontal a representaçóes normalizadas, privilégios e estruturas de poder que definem as desigualdades sociais profundamente racializadas no Brasil (Hasenbalg, 1979, 1998; Inspir, 1999; Henriques, 2001; Nascimento, 1977, 1989). Durante esse episódio, as/os ativistas na favela revelaram um senso distinto de geografia social urbana: da perspectiva daqueles que clamavam por autonomia e cidadania, o Jacarezinho não era um espaço a ser sistematicamente isolado do resto da cidade como uma área ameaçadora, socialmente poluída e portanto dominada pelo mal, mas um lugar cuja história, organização política e projetos de justiça social demandavam respeito e reconhecimento. ${ }^{7}$ As notícias e opiniões expressas por políticos, funcionários públicos e acadêmicos eram reações contra as demandas das/dos ativistas da favela, e desse modo expressaram o correspondente desejo pelo restabelecimento de relações sociais normalizadas, ou seja, devidamente hierarquizadas. Para as/os ativistas negras/os, tornou-se claro que tal normalização implicava a marginalização política, racial e espacial das favelas. Documentar e analisar os conflitos entre a favela e essas práticas e representações hegemônicas são os propósitos centrais deste artigo. 
João H. Costa Vargas. Apartheid brasileiro...

Essa discussão estrutura-se da seguinte forma. Em primeiro lugar, descrevo como a mídia interpretou os portões instalados no Jacarezinho em 2001. Nesta parte, sistematizo como os jornais, o noticiário de TV e o debate público que se seguiu combinaram - de maneira silenciosa, mas efetiva - raça e espaço urbano em uma lógica por meio da qual os ativistas da favela eram criminalizados. Em seguida, defino favela como uma realidade espacial socialmente construída e profundamente disputada, e descrevo brevemente a história política da Associação de Moradores do Jacarezinho. Parte da singularidade do Jacarezinho está em suas alianças políticas transnacionais (em curso) estabelecidas com ex-membros dos Panteras Negras em Los Angeles (Vargas, 2003). Para contextualizar o conflito político entre a favela e seus adversários, e refletir sobre as possíveis agendas de pesquisa que podem emergir a partir daí, discuto como a produção acadêmica pertinente no Brasil e nos Estados Unidos têm abordado raça e espaço urbano. Concluo com uma discussão sobre as implicações teóricas e políticas mais amplas de como raça e espaço urbano são componentes essenciais de um senso comum hegemônico que sustenta e se alimenta da marginalização histórica imposta aos negros.

A exclusão geográfica, tão bem expressa na manutenção, demonização e contínua desumanização das favelas, funciona como uma metáfora e como a corporificação concreta irrefutável de um sem-número de outros tipos de marginalização às quais as/os negras/os estão submetidas/os no Brasil - nas áreas de moradia, emprego, saúde, educação e representação política. É apenas confrontando a natureza multifacetada do racismo antinegra/o que seremos capazes de compreender (e contribuir para a eliminação de) as desigualdades raciais óbvias que caracterizam as relaçóes sociais brasileiras. Da mesma maneira que o mito da democracia racial precisa ser desafiado e desconstruído (D’Adesky, 2001; Guimarães, 1999; Nascimento, 1989; Silva \& Hasenbalg, 1992), tam- 
bém se deve abordar criticamente outro aspecto menos discutido da auto-imagem mítica brasileira que a sustenta e é dela uma consequiência: a ausência de segregação racial. Pesquisa inovadora realizada pelo arquiteto Ney dos Santos Oliveira (2002, 2001, 2000, 1999), assim como biografias como a de Benedita da Silva (Mendonça \& Benjamin, 1997) e etnografias conduzidas por Goldstein (2003), Sheriff (2001), Vargas (2003, 2004b) e Zaluar (1985), por exemplo, sugerem que, no Rio de Janeiro, pelo menos, não somente padrões de ocupação urbana estão inexoravelmente ligados à raça, mas também conceituações sobre raça derivam das várias formas como o espaço urbano é compreendido.

A despeito do potencial prático e teórico do trabalho acadêmico, a crítica mais incisiva assim como alternativas políticas às formas históricas de marginalização espacial e racial no Brasil emergem da colaboração entre militantes de favelas do Rio e seus aliados nos Estados Unidos. Essa colaboração oferece visões efetivas que desafiam a criminalização das/dos negras/os que vivem em favelas. Como a conclusão deste artigo irá sugerir, essa parceira deveria ser tomada como um modelo para o desenvolvimento de esforços teóricos e práticos para o alcance da justiça social e do fim do racismo brasileiro - silencioso mas contundente, persistente e claramente expresso em padrōes de segregação residencial.

\section{O condomínio-favela}

No dia 28 de julho de 2001, O Dia, o jornal de maior circulação no Rio de Janeiro, relatou em sua primeira página que portôes instalados recentemente isolavam o Jacarezinho do resto da cidade. Uma grande fotografia colorida ilustrava a notícia: nela há um homem jovem, de costas, segurando a mão de uma menina ao atravessar um portão de folhas de metal cor de cobre com cerca de 3,5 metros de altura. A passagem 
João H. Costa Vargas. Apartheid brasileiro...

semi-aberta do portão revelava uma das vielas estreitas da comunidade onde quatro crianças brincavam no chão coberto acimentado, entre casas e prédios baixos. A legenda da foto, curta e em negrito, dava o tom do artigo que aparece nas páginas internas do jornal:

\section{Jacarezinho Fechado a Cadeado}

Inspirada nos condomínios [ricos] da Zona Sul, segunda maior favela do Rio instala portôes nas vielas e câmeras de vídeo em pontos estratégicos. Só que o inimigo é outro: os abusos da polícia, segundo as lideranças. Iniciativa é polêmica por deixar os traficantes ainda mais protegidos em seus guetos. (p. 1)

$\mathrm{O}$ artigo de página inteira, ainda que não criticando abertamente o trabalho dos ativistas do Jacarezinho, iniciou e alimentou a controvérsia ao dar detalhes extensos sobre a história dos portóes e de seu impacto sobre a polícia e os traficantes de drogas. $\mathrm{O}$ experimento, de acordo com o artigo, havia começado alguns anos antes quando portóes similares foram instalados nas favelas do Pica-Pau Amarelo e das Malvinas, que são parte da comunidade do Jacarezinho. A reação da polícia na ocasião foi rápida, e os portões foram derrubados sem resistência.

Dessa vez, no entanto, ativistas da favela pareciam melhor preparados para negociar com a polícia e a mídia. A nova liderança local, eleita em janeiro de 2000, prometia começar um novo capítulo na forma como as favelas se organizam e se relacionam com a sociedade em geral. Antônio Carlos Rumba Gabriel, também conhecido como Rumba, presidente eleito da Associação de Moradores, garantiu que iria colocar o Jacarezinho de volta no cenário político da cidade, recuperando dessa forma uma longa história de mobilização. ${ }^{8}$ A comunidade era conhecida, durante a ditadura militar dos anos 60, como "Moscouzinho". O nome refletia o grande número de esquerdistas e organizações políticas clan- 
destinas que operavam na área, protegidas pela vantagem geográfica advinda da topografia ondulada - a qual proporcionava fácil vigilância dos pontos mais altos da comunidade - e pelo labirinto de ruas estreitas que tornava o acesso difícil aos carros da polícia.

A gestão de Rumba começou com impacto na mídia e no cenário político local. O jornal eletrônico Notícia e Opinião, um fórum conhecido em que questôes políticas contemporâneas eram debatidas por políticos, artistas, intelectuais e ativistas, deu ampla cobertura à agenda da nova gestão. Ameaçando "descer o morro e tomar o que é nosso", os ativistas demandavam o fim da brutalidade policial, mais e melhores programas sociais com foco em saúde, educação e capacitação para o trabalho, e transporte público. Em suma, demandavam cidadania plena. Rumba e seus colaboradores queriam para a favela aquilo que era tido como seu direito e faziam alusões à ajuda que conseguiriam dos traficantes armados para alcançar seus objetivos, caso suas demandas não fossem atendidas (no.com.br, 19 ago. de 2000).

\section{Portões, câmeras e traficantes de drogas}

Embora alguma atenção tenha sido dada às demandas de cidadania daquelas novas vozes políticas vindas do Jacarezinho, a maior parte do noticiário da imprensa, dos intelectuais e dos políticos focalizaram sua atenção na sugestão de que o movimento da comunidade teria a ajuda dos traficantes de droga e de suas armas. Tal sugestão gerou uma enxurrada de comentários negativos por parte de políticos conhecidos, como Milton Temer, ex-deputado federal (PT) e atual membro da Executiva Nacional do Partido Socialismo e Liberdade (P-SOL), o ex-deputado estadual Aloísio de Oliveira, de intelectuais como Ignácio Cano, do defensor público Rodrigo Terra, do ativista de direitos humanos James Cavallaro 
João H. Costa Vargas. Apartheid brasileiro...

(no.com.br, ago. 2000, p. 18-20) e do deputado estadual Carlos Minc (RJ), à época presidente da Comissão Contra a Violência e a Impunidade da Assembléia Legislativa do estado do Rio de Janeiro (Petry, 2001, p. C1).

O Dia insistia no tema. Embora o artigo de página inteira incluísse a declaração de Rumba afirmando sua independência dos traficantes de drogas, e que isso era também verdadeiro em relação às câmeras e aos portôes, a conclusão trazia uma descrição do evento com as seguintes frases:

O problema é que até uma criança que acredita em Papai Noel sabe que nada acontece em uma favela sem o consentimento dos traficantes. As câmeras foram liberadas após seis meses de uma longa negociação. Os traficantes de droga estavam preocupados que isto os afetaria negativamente. É assim que funciona em uma comunidade localizada em meio ao fogo cruzado. (Braga, 2001, p. 4)

Tornou-se claro, assim, que, até prova em contrário, ativistas da favela estavam ligados ao tráfico de drogas de quem, por um lado, recebiam contribuições monetárias e proteção armada e, por outro, cumpriam ordens e regras sob a ameaça constante e autoritária de achacamento e morte. ${ }^{9}$

Nesse sentido, a matéria de O Dia forneceu o modelo segundo o qual o jornal de maior circulação no Brasil, a Folha de S.Paulo, escreveria sobre o ousado experimento. A matéria de página inteira da Folha trazia a manchete "Favela carioca cria o condomínio-favela". Outra manchete em letras menores dizia "Violência: Associação de Moradores do Jacarezinho coloca portões e câmeras para controlar a polícia". De maneira significativa, entretanto, o primeiro artigo, no canto superior esquerdo da página, tinha o título "Líder nega laços com o tráfico de drogas". O foco era em Rumba, que declarou: 
Revista de Antropologia, São Paulo, USP, 2005, v. 48 No 1.

Eu nunca tive laços com os traficantes. Nós, presidentes de associações de moradores, vivemos em comunidades onde existe o tráfico de drogas e temos de conviver com isto. Mas nós não interferimos nas atividades deles e eles nos deixam em paz. (Folha de S.Paulo, 25 jul. 2001, p. C1)

A despeito de Rumba negar continuamente o envolvimento com o tráfico de drogas, esse veículo da mídia de São Paulo assim como a polícia do Rio prontamente formaram suas opiniōes sobre o ativista político e seu grupo. No referido artigo da Folha foi mencionado que ele havia passado a manhã na $21^{\underline{a}} \mathrm{DP}$, a delegacia de polícia local, explicando por que ele tinha anotado o número da placa de uma viatura policial e ligado para o comandante da área pedindo explicações sobre a presença da polícia. Essa visita forçada à delegacia na verdade constituía um dos muitos incidentes que marcaram a curta carreira de Rumba como presidente da Associação de Moradores, algo que eu mesmo presencei como rotineiro (Vargas, 2003): "Eu queria saber se aquela blitz era legal, mas... [o policial que me prendeu] pensou que eu estava alertando os traficantes" (25 jul. 2001, p. C1).

Enquanto a Folha de S.Paulo deu voz a Rumba em suas páginas para que ele contasse a sua versão, o tom geral da matéria contextualizava a perspectiva do ativista de tal maneira que seus laços com os traficantes de drogas tornavam-se quase transparentes. $\mathrm{O}$ artigo que se seguiu ao analisado acima, intitulado "Presidente da associação foi morto", começava com a frase: "Não é incomum líderes comunitários serem acusados de envolvimento, ao menos indireto, com o tráfico". Para apoiar essa afirmação, a matéria citava Michel Misse, professor de Sociologia da Universidade Federal do Rio de Janeiro (UFRJ) e fundador do Instituto de Segurança Pública. Misse argumentou que: 
João H. Costa Vargas. Apartheid brasileiro...

A convivência é inevitável. Estas pessoas vivem onde o tráfico vive. Líderes comunitários têm que tolerá-los, senão eles são expulsos de suas comunidades. Há também o risco de assassinatos. E existem presidentes de associações de moradores que trabalham com os traficantes. (25 jul. 2001, p. C1)

Os comentários desse especialista fornecem suposta validade científica à suspeita expressa por políticos e pela mídia. Uma vez confirmada, a relação de Rumba com o tráfico pode ser reconstruída a partir de eventos ocorridos muito antes dos portôes e das câmeras terem sido instalados. Essa matéria em particular conclui lembrando aos leitores que, em maio de 2000, Rumba fora acusado de trabalhar para os traficantes. O contexto da acusação foi o seguinte: após a morte desnecessária e inexplicável de um jovem no Jacarezinho, a qual vizinhos disseram ter sido causada pela polícia, dois ônibus e um carro foram incendiados como sinal de protesto. Informantes da polícia revelaram posteriormente que a manifestação foi organizada pelos traficantes de drogas, e Rumba foi uma das pessoas acusadas de ajudá-los. É sugestivo que, enquanto o foco da reportagem era Rumba e suas ligações - não comprovadas - com o tráfico, perguntas sobre a polícia e sua participação na morte do jovem nunca foram feitas.

Deve-se enfatizar que o abuso policial contra moradores de favelas, em sua maioria pobres e negras/os, faz parte de um padrão histórico ainda em curso. No Rio de Janeiro, a polícia matou 900 pessoas entre janeiro e agosto de 2003, sendo que $75 \%$ dessas mortes ocorreram em favelas (Jeter, 2003). No período de um mês, a polícia do Rio de Janeiro matou duas vezes e meia mais pessoas do que a polícia de Nova York em um ano (Human Rights Watch/Americas, 1997). Contrário à percepção pública e aos pedidos por uma maior militarização na "guerra contra o crime", feitos frequientemente por funcionários públicos e setores organizados da sociedade civil, os índices de criminalidade violenta no 
Revista de Antropologia, São Paulo, USP, 2005, v. 48 No 1.

Rio de Janeiro têm diminuído constantemente. Nesse clima de pânico moral, entretanto, os números de execuções por policiais crescem de maneira alarmante. Enquanto 427 "suspeitos" foram mortos pela polícia em 2000, esse número subiu para 900 em 2002. É de conhecimento geral que os "suspeitos" são jovens negros mortos nas operações militares de rotina conduzidas pelas polícias nas favelas (Amar, 2003; Human Rights Watch/Americas, 1997). Paul Amar lembra que

Tal tendência, caso continue, faria o número total de execuçôes policiais chegar a mais de 1.500 em 2003 só no estado do Rio de Janeiro, alcançando paridade com Bagdá ... [que] sofreu cerca de 1.700 mortes de civis naquele ano da guerra [de ocupação]. (2003, p. 38)

Os casos constantes de abuso policial são parte de um padrão persistente e emblemático do racismo antinegra/o que permeia a sociedade brasileira (Cano, 1997; Holloway, 1997; Khan, 1999, 2002; Paixão, 1995; Silva, 1998). ${ }^{10}$ Se os jornais e os especialistas tivessem prestado atenção a tais padrões de abuso policial racializado, a justificativa dos ativistas da favela para os portóes e as câmeras teria sido melhor compreendida. De fato, restringir o uso da força pela polícia foi o objetivo principal do condomínio-favela. Além do mais, as câmeras permitiram a gravação de casos de má conduta policial, tais como extorsão, espancamentos e tiroteios - todos amplamente registrados por organizaçôes nacionais e internacionais de direitos humanos e alguns órgãos de imprensa, mas raramente discutidos por "especialistas", comentaristas e o público em geral fora das favelas. ${ }^{11}$ Esse material gravado constituiria evidência inegável em apoio às denúncias dos ativistas, as quais, segundo Rumba declarou, "não são normalmente levadas a sério" (Folha de S.Paulo, 25 jul. 2001, p. C1). 
Similarmente, a instalação das câmeras constituiu um esforço de restringir o tráfico de drogas. As negociações com os traficantes locais para instalá-las tinham sido tão difíceis exatamente porque estes sabiam muito bem o que elas significariam: suas atividades teriam de acontecer fora do campo de visão das câmeras. Rumba, de fato, tem uma trajetória pública de denúncias contra o tráfico de drogas no Jacarezinho. Ele apoiou e participou de uma conhecida série de reportagens de O Dia que descreveu, fotografou e analisou as várias facetas do comércio e consumo de drogas na comunidade. ${ }^{12}$

\section{Criminalizando os moradores da favela: as noçôes silenciosas que orientam as representações de raça e espaço urbano}

Em vez de considerar seriamente as declarações dos ativistas da favela, tanto a Folha de S.Paulo quanto O Dia sugeriam uma conexão entre o condomínio-favela e os traficantes de drogas. Tal conexão foi "confirmada” não apenas explicitamente, mas também por uma série de mecanismos mais sutis. Um desses mecanismos foi a justaposição das descriçôes da favela com relatos de traficantes conhecidos que eram ora suspeitos de infiltrar associações de moradores ora estavam foragidos da polícia. Na reportagem de página inteira da Folha de S.Paulo sobre os portóes do Jacarezinho, todos os títulos e mesmo o conteúdo dos artigos seguem o roteiro. Eis alguns títulos de artigos que são sugestivos dessa tentativa de ligar a favela à violência e ao crime: "Presidente de associação de moradores foi morto" e "Polícia prende cinco supostos traficantes de drogas", que servia como introdução à seção final de comentários, no pé da página (p. C1).

As fotos coloridas no meio da reportagem reforçam a idéia de "outro" conferida à favela. A foto no alto da página era a mesma utilizada 
Revista de Antropologia, São Paulo, USP, 2005, v. 48 No 1.

por O Dia na descrição dos portóes e das câmeras na primeira página: um jovem e uma menina entrando pelo portão de metal aberto. Abaixo dessa, outra foto traz uma visão panorâmica do Jacarezinho, composta de uma infinidade de casas construídas próximas umas às outras. A terceira foto mostra Rumba - negro, 47 anos, de terno e gravata nas cores preta, vermelha e verde do Pan-africanismo -, apontando para o horizonte com o indicador e o braço esquerdo.

As fotos foram um componente importante na reportagem de página inteira da Folha de S.Paulo. Os portões, a favela e Rumba pertencem a um mundo descrito como distante, pobre e perigoso - especialmente para os leitores de São Paulo, onde o senso comum construiu o Rio de Janeiro como uma cidade bela mas repleta de favelas e, portanto, claramente perigosa. Um mapa próximo à foto de Rumba fornece a representação gráfica da localização do Jacarezinho em relação à cidade do Rio de Janeiro e ao País. O mapa mostra a localização da favela em várias escalas - nacional, regional e municipal - e é complementado por dados básicos fornecidos ao leitor de modo direto: "De acordo com a associação de moradores, 150 mil pessoas moram no Jacarezinho", "Existem cerca de 45 mil barracos na comunidade, que ocupam uma área de 354 mil metros quadrados" (Folha de S.Paulo, 25 jul. 2001, p. C1).

As imagens e os artigos, em conjunto, constituem uma declaração sugestiva - ainda que indireta - sobre as conexões entre favelas, criminalidade e raça. Os portóes e as câmeras, conforme relatado repetidamente nos artigos, iriam beneficiar traficantes de drogas e atrapalhar o trabalho da polícia, tornando-se assim instrumentos óbvios da ilegalidade. De maneira significativa, as fotos do portão e da favela mostravam o Jacarezinho como uma comunidade cujos detalhes só poderiam ser vistos por meio de aberturas furtivas: a foto maior do portão de metal, conforme descrita anteriormente, permitia apenas uma olhada rápida da ruela de cimento estreita da favela; a foto panorâmica do Jacarezinho 
João H. Costa Vargas. Apartheid brasileiro...

que aparecia na Folha, da mesma forma, era emoldurada por uma janela aberta sugerindo uma realidade que está normalmente oculta do que se vê todos os dias e está, de fato, isolada do resto da cidade. Enquanto se pode argumentar que a janela nessa foto era simplesmente uma tentativa de manter uma referência artística (portões, janelas, aberturas etc.), perdemos de vista aspectos importantes sobre a forma como a notícia é narrada se ignorarmos as conexões, ainda que tácitas, entre áreas urbanas habitadas por não-brancos pobres, por um lado, e a criminalidade, por outro. Tais representaçôes ganham mais substância com a foto de Rumba, na qual sua aparente raça era irrefutável, assim como seu local de residência e sua suposta conexão com a ilegalidade. Como que a reunir as várias imagens e os relatos escritos, a última informação no mapa que localizava o Jacarezinho, e que aparece ao lado da foto de Rumba, diz o seguinte: "De acordo com a polícia, a facção criminal Comando Vermelho domina o Jacarezinho" (Folha de S.Paulo, 25 jul. 2001, p. C1).

O noticiário local da Rede Globo adotou a mesma postura. Na semana posterior à publicação da reportagem sobre o condomínio-favela em $O$ Dia, reportagens diárias sobre a controvérsia foram ao ar. Rumba foi entrevistado brevemente na primeira reportagem, a qual foi seguida por uma entrevista com Carlos Minc, deputado estadual no Rio de Janeiro. Minc expressou a visão de que os ativistas das favelas normalmente trabalham muito próximos aos traficantes de drogas - quando não de fato trabalham para eles. Essa seria a primeira e última aparição de Rumba no noticiário local que tratou dos portóes do Jacarezinho. Representantes de ONGs, políticos e funcionários públicos, entretanto, tiveram acesso pleno aos programas e confirmaram a interpretação dada aos fatos pelos jornais do Rio e de São Paulo. O tempo reduzido para o ativista negro em comparação àquele para os que são considerados comentaristas respeitáveis revela onde está o compromisso da Rede Globo. Também revelador foram as expressões faciais da apresentadora da 
Rede Globo, as quais não deixavam dúvida alguma em quem ela acreditava. Enquanto tinha uma expressão franzida após a entrevista com Rumba, apresentou os outros convidados com um sorriso confiante, olhando o monitor que os mostrava em um belo cenário costeiro.

As várias entrevistas na TV de Carlos Minc foram emblemáticas. Exguerrilheiro, branco e ainda hoje, como em 2001, deputado estadual pelo Partido dos Trabalhadores, ele não hesitou em ligar a Associação de Moradores do Jacarezinho ao que chamava de "tráfico". Minc não parecia consciente do fato de que, ao sumariamente condenar os ativistas da favela por sua cumplicidade com os traficantes de drogas, o fazia utilizando-se de preconceitos históricos e duradouros contra negras/os, especialmente aqueles que vivem em favelas. A miopia de Minc é um sintoma da incapacidade ou falta de vontade da esquerda brasileira de entender e produzir uma crítica efetiva das relações raciais. Embora o Partido dos Trabalhadores tenha um programa de justiça social de mérito inegável, e a despeito de suas tímidas tentativas de organizar um aparato estatal em nível nacional no Executivo e na área legal para o combate à discriminação racial, uma visão tradicional das relaçóes sociais que considera raça um epifenômeno de classe ainda domina a orientação do partido. ${ }^{13}$

Como tais noçôes sobre favelas tornaram-se dominantes? Como os moradores de favelas vêem as imagens, práticas e políticas negativas que sistematicamente os desumanizam? Para entender as implicações da forma como a mídia e os atores públicos interpretam os ativistas e moradores do Jacarezinho, uma análise do lugar que as favelas ocupam na paisagem política e geográfica do Rio de Janeiro é necessária. 
João H. Costa Vargas. Apartheid brasileiro...

\section{A favela do Jacarezinho: espaço urbano e história política}

No Rio de Janeiro, uma cidade global que, de acordo com o Censo de 2000, tem mais de 6 milhôes de habitantes, onde existem mais de 600 favelas que acolhem mais de $40 \%$ dos moradores da cidade (Burgos, 1999), como entender teoricamente a favela? Para responder a essa questão, deve-se primeiro considerar as dimensōes políticas e ideológicas que definem os espaços sociais e urbanos. Em The Production of Space, Henri Lefebvre notou que "Espaço (social) é um produto (social)" (1991, p. 26; original em itálico). Como tal, o espaço é produzido por relações sociais e as reproduz. Uma vez que as relaçôes sociais são determinadas por diferenças de poder, ao mesmo tempo em que as relações sociais incidem sobre as formas e manifestações de poder, o espaço urbano está profundamente implicado (e é conformado) no processo em que hierarquias sociais se concretizam em um dado momento histórico. A existência de um espaço neutro, prontamente transparente, é uma ilusão: todos os espaços urbanos são produtos de lutas históricas de poder, e as relações sociais derivadas de tais lutas tornam-se espacializadas de acordo com a ordem política hegemônica: "cada modo de produção (...) produz um espaço, seu próprio espaço” (Lefebvre, 1991, p. 31).

Enquanto as relações espaciais resultantes que expressam subordinação e dominação são normalmente mantidas através do consenso, existe ainda a freqüente necessidade de coerção explícita, especialmente em espaços urbanos como os guetos nos Estados Unidos, na África do Sul sob o regime do Apartheid, ou as favelas brasileiras. Em tais espaços urbanos, há resistência freqüente - alguns diriam constantemente, embora não obviamente (Kelley, 1997; Scott, 1990) - contra a subordinação social e espacialmente racializadas, impostas pela sociedade mais ampla. Enquanto instrumento central de coerção em sociedades burguesas, a polícia está na linha de frente de ataque - tanto preventivo quanto 
reativo - contra estratégias políticas de resistência articuladas por comunidades marginalizadas. A polícia implementa, em sua prática e orientação, um entendimento normalizado e consensual sobre aqueles a quem reprime (Gooding-Williams, 1993; Rothmiller, 1992). Que a polícia seja uma presença historicamente ofensiva e persistente nas comunidades negras norte-americanas (Davis, 1992; Donziger, 1996; Miller, 1996; Parenti, 2000) e nas favelas brasileiras (Holloway, 1997; Paixão, 1995; Silva, 1998) comprova a natureza conflituosa dos espaços urbanos excludentes e profundamente racializados. Exclusão e racialização são, pois, dois lados da mesma moeda - a polícia galvaniza tal princípio de modo exemplar.

Para compreender como diferenciais de poder determinam a construção social das favelas - ou seja, para decifrar o espaço urbano (Lefebvre, 1991, p. 38) -, é preciso focalizar as práticas espaciais da sociedade mais ampla. Dado que as práticas espaciais implicam (histórica e contemporaneamente) práticas sociais específicas, decifrar o espaço requer um entendimento das compreensões hegemônicas sobre o mundo social hierarquias, privilégios e exclusões. Tais compreensões hegemônicas, por sua vez, dão forma concreta (ao mesmo tempo em que derivam de concepçóes e práticas relacionadas) aos espaços urbanos. Assim, o espaço da favela é resultado dinâmico de como a dominação social é conceitualizada, aplicada e contestada (Foucault, 1980; Harvey, 1989).

O conceito e a experiência das favelas têm significados históricos, sociais, políticos e raciais que variam de acordo com a posição social dos atores políticos que deles se utilizam. Da mesma forma que espaços sociais são produtos de relações sociais, favelas são produtos de lutas políticas. Para contextualizar as lutas políticas em torno da definição, das experiências e da consolidação das favelas, descreverei brevemente alguns pontos-chave em termos de políticas públicas nos últimos 50 anos, as respostas articuladas por moradores de favelas durante esse período, e as 
João H. Costa Vargas. Apartheid brasileiro...

agendas políticas contemporâneas que resultaram desse processo e que estão sendo implementadas por grupos organizados nas comunidades pobres do Rio. Os dois momentos-chave são os seguintes: em primeiro lugar, os impactos negativos que a ditadura militar (1964-1985) teve na organização dos moradores de favelas. Em segundo, os efeitos do comércio de drogas nas redes de sociabilidade e associações de moradores das favelas durante a década de 1980. É apenas entendendo, ainda que resumidamente, os eventos históricos em torno desses dois eixos que podemos decifrar os significados dos esforços recentes, por parte dos moradores de favela, para recuperar formas de organização autônomas e demandar cidadania plena. ${ }^{14}$ Tais esforços derivam de uma meta mais abrangente, a saber, a autodefinição, que constitui instrumento crucial de resistência e transformação, sobretudo em contextos marcados por racialização desumanizadora, cujo efeito, entre outros, é esvaziar comunidades negras de sua agência política, transformando-as, assim, em meras espectadoras passivas dos processos políticos e históricos que as atingem.

Em 1968, no auge da repressão do regime militar, um decreto redefine radicalmente as organizações e as associações de moradores existentes. De acordo com as novas regras, a burocracia militar supervisiona estatutos, membros, eleições e programas das associaçóes de moradores. Quase que imediatamente a ditadura militar é bem-sucedida no que as igrejas e as administrações municipal e estadual estavam tentando fazer há 60 anos: reprimir efetivamente as favelas. Com a presença das tropas nas favelas e com a intimidação, tortura e assassinato dos líderes mais ativos, as associações de favelas tornaram-se postos do Estado. ${ }^{15}$

Entre o fim da década de 1960 e meados da década de 1970, vários programas de remoção foram implementados. Embora fossem consistentes com os planos do Estado e da igreja de "limpar" a cidade, até meados da década de 1960 encontraram resistência organizada e, portanto, nunca puderam ser plenamente postos em prática. A presença 
Revista de Antropologia, São Paulo, USP, 2005, v. 48 No 1.

dos militares, no entanto, produz uma história diferente. $\mathrm{O}$ assassinato de líderes comunitários e a violência imposta às comunidades garantiram que, entre os anos de 1968 e 1975, cerca de 100 mil pessoas fossem removidas de favelas e assentadas em projetos residenciais. Mais de 60 favelas foram destruídas, algumas das quais simplesmente incendiadas pelos militares que, para garantir sua eliminação, impediam bombeiros de responder às chamadas de socorro. ${ }^{16}$

Os efeitos políticos do período militar nas favelas foram profundos. Enquanto muitas das comunidades que foram alvo das remoções conseguiram se reconstituir, as associações de moradores foram irremediavelmente afetadas. Mesmo no período de redemocratização iniciado em fins dos anos 70, a dinâmica da representação política local, em sua maior parte, continuou seguindo os parâmetros estabelecidos pela ditadura: as associaçóes de moradores, com freqüência, cumpriam o papel de representantes do Estado no interior das favelas. Ainda com as eleições do esquerdista Leonel Brizola para governador do estado em 1982 - e a despeito dos múltiplos esforços de sua administração para urbanizar as favelas e implementar políticas de direitos humanos para os pobres com a reforma da polícia, entre outras iniciativas -, as organizaçóes locais de favelas não conseguiram romper com o modelo de atuação herdado. Seus estatutos não foram revisados, assim como não o foram seus processos eleitorais freqüentemente marcados por falta de transparência. ${ }^{17}$

A década de 1980 refez a dinâmica política das favelas em novas configurações nas quais o jogo do bicho e, em uma escala muito maior, o comércio de drogas começaram a dominar o cotidiano e as organizações locais. Jovens chefes do tráfico detinham poder de vida e morte nas favelas e, freqüentemente, ameaçavam expandir seu regime de terror não apenas para outras favelas mas também para bairros vizinhos a estas para o "asfalto"..$^{18}$ Armados com um arsenal sofisticado e abastado, os traficantes desafiavam abertamente a polícia e o Estado. Muitas das 
João H. Costa Vargas. Apartheid brasileiro...

associações de moradores de favelas tornaram-se aparelhos de uma das facções do tráfico de drogas - Comando Vermelho, Terceiro Comando e, mais recentemente, Amigos de Amigos.

É preciso enfatizar o seguinte: ao contrário da crença popular e das justificativas dadas pela polícia para suas operações de repressão, as favelas do Rio não produzem cocaína ou armas, nem retêm os lucros derivados da comercialização dessas. Como acontece nos guetos das cidades nos Estados Unidos, as favelas são apenas pontos-de-venda, nodos em uma rede transnacional, e a grande maioria dos consumidores de drogas são das classes abastadas. Os verdadeiros chefes do tráfico certamente não estão nas favelas nem são originários de favelas. Ainda assim, elas não apenas fornecem força de trabalho barata, numerosa e dispensável, mas também, devido a topografia montanhosa e as ruas estreitas e tortuosas, constituem territórios que podem ser facilmente protegidos contra as facções rivais e a polícia.

Tais considerações, entretanto, dificilmente fazem parte das representações e discussões contemporâneas acerca das favelas. Ao mesmo tempo em que o comércio de cocaína e sua militarização estavam sendo estabelecidos nas comunidades mais pobres do Rio, a década de 1980 também produziu considerável desemprego que atingiu os pobres e os moradores de favelas desproporcionalmente. ${ }^{19}$ No Jacarezinho, por exemplo, o crescimento agudo do desemprego se deveu, de modo significativo, às demissões massivas na companhia General Electric, que afetaram um dos poucos segmentos da comunidade que participavam do mercado de trabalho formal. Com a ausência de análises críticas sobre as condições nas quais o comércio de drogas floresceu, a longa história de estereótipos racializados e negativos associados às favelas foi reciclada por meio da inclusão dos efeitos das drogas nas comunidades supostamente já degradadas, amorais e violentas. ${ }^{20}$ Embora o número de pessoas - a maioria jovens do sexo masculino entre as idades de 10 e 25 anos - 
Revista de Antropologia, São Paulo, USP, 2005, v. 48 no 1.

que fazem parte do comércio de drogas como um exército de mão-deobra rotativa represente uma proporção infinitesimal da população da favela, o comércio de drogas e a violência que este gera têm dominado tanto a vida cotidiana das favelas como o imaginário coletivo mais amplo da cidade. ${ }^{21}$ As conversas do dia-a-dia, as estratégias do Estado para garantir o cumprimento da lei e a grande mídia oferecem testemunhos desse imaginário. Quando a Operação Rio, em 1994, pôs os militares nas ruas, os tanques apontados para as favelas e suspendeu os direitos civis dos moradores desses lugares, a história estava se repetindo. ${ }^{22} \mathrm{O}$ relatório de 1997 do Human Rights Watch concluiu que a operação foi "pontuada pela tortura, detenções arbitrárias e buscas sem mandato, além de pelo menos um caso de uso letal de força desnecessário". ${ }^{23}$

$\mathrm{Na}$ ausência de uma perspectiva crítica, imagens do senso comum sobre negras/os e favelas reforçam tanto percepções socialmente compartilhadas quanto políticas públicas dirigidas às comunidades marginalizadas. Quando o O Dia, a Folha de S.Paulo e a Rede Globo põem o foco nos moradores de favelas, estes dão credibilidade ao conhecimento hegemônico tácito, reelaboram-no, e afirmam as interconexões entre raça e espaço. Cognitivamente associados à poluição social e à ameaça iminente que deve ser preventivamente reprimida, as favelas e seus moradores são freqüentemente retratados como moralmente corruptos e desumanos. A conexão poderosa que se estabelece entre raça e espaço urbano perpetua os estereótipos raciais negativos. Essa perpetuação ocorre de forma curiosa (devido ao modo silencioso como ocorre) e funciona conforme um mecanismo efetivo de manutenção das hierarquias sociais.

O que nos diz, então, o debate acadêmico crítico sobre esse fenômeno? Como raça e espaço urbano são conceitualizados por estudiosos da sociedade brasileira? Que utilidade pode ter a literatura sobre segregação espacial por raça nos Estados Unidos quando buscamos uma interpretação dos eventos no Rio de Janeiro? 
João H. Costa Vargas. Apartheid brasileiro...

\section{Raça e espaço urbano: como estudos sobre as cidades brasileiras e americanas podem ser combinados}

Enquanto existem várias publicações importantes que focalizam diretamente como o espaço urbano no Brasil é conceitualizado, ocupado, politizado e transformado por meio de lutas sociais e históricas (Caldeira, 2000; Holston, 1989; Zaluar, 1985, 1994), raça não aparece como uma categoria analítica central nesses trabalhos. É o caso de se dizer que raça pode ser lida nas entrelinhas desses textos. Nas análises que têm foco no Rio de Janeiro (Goldstein, 2003; Sheriff, 2001; Zaluar e Alvito, 1999), está claro que os grupos sociais que ocupam as favelas e comunidades pobres são desproporcionalmente homens e mulheres afro-descendentes. Embora esses trabalhos com freqüência não o façam de maneira explícita, argumento que o que eles descrevem são aspectos da segregação espacial por raça.

Outra maneira de refletir sobre o silêncio acadêmico em torno de raça e espaço urbano é contextualizá-lo como parte do arcabouço hegemônico intelectual e político mais geral, o qual, ainda que não voluntariamente, ratifica o mito brasileiro da democracia racial. Tal abordagem, entretanto, requereria extensiva análise histórica e teórica das várias correntes intelectuais no Brasil, o que está além dos objetivos e do escopo deste artigo. ${ }^{24}$

Ney dos Santos Oliveira, geógrafo urbano e arquiteto, é um dos poucos autores que trabalham os processos urbanos brasileiros explicitamente tratando da segregação por raça como um elemento central para o entendimento de como grandes cidades dão dimensão espacial a formas históricas de exclusão racializada (2002, 2001, 2000, 1999). Utilizando-se do trabalho já clássico de Massey e Denton (1993), American Apartheid (1993), além de dados extensivos do Censo brasileiro e de pesquisas elaboradas e conduzidas pelo próprio grupo de pesquisa, Oli- 
Revista de Antropologia, São Paulo, USP, 2005, v. 48 no 1.

veira discute como favelas são ocupadas por um número desproporcional de negras/os em relação a seu percentual na população da cidade.

Em um de seus estudos, baseado em uma pesquisa conduzida em uma favela em Niterói, cidade da Região Metropolitana do Rio de Janeiro, Oliveira demonstra como essa comunidade tem um índice de dissimilaridade de 60. Isto siginifica que, enquanto Niterói tem 70\% de brancos e $30 \%$ de negras/os (o que inclui auto-identificados pretos e pardos), a favela tem $70 \%$ de negras/os e 30\% de brancos. De modo a refletir a composição racial da cidade, $60 \%$ das/dos negras/os da favela teriam de se mudar para algum outro lugar, daí o índice de dissimilaridade (2002, p. 14).

De acordo com o modelo de Massey e Denton, um índice de dissimilaridade de 60 descreve segregação moderada. Entretanto, no caso de Niterói, esse nível aparentemente moderado de segregação não revela a dimensão completa da experiência de marginalização e isolamento das/ dos negras/os naquela cidade. A pesquisa de Oliveira demonstra como, até mesmo no interior de comunidades marginalizadas, as/os negras/os vivenciam desvantagens relativas em relação aos brancos. Por exemplo, a área com a menor renda mensal corresponde àquela onde as/os negras/os se encontram em maior proporção. Igualmente relevante, em toda a favela os brancos têm consistentemente os maiores salários. Além do mais, e revelando como a mobilidade econômica e social está relacionada à raça, enquanto as/os negras/os têm em média 27,4 anos de residência na favela, os brancos têm 19,4 (2002, p. 15). ${ }^{25} \mathrm{O}$ dado sugere que os níveis de segregação e marginalização que as negras/os enfrentam são multidimensionais e cumulativos ao longo do tempo. Enquanto negras/os vivenciam um grau de segregação aparentemente moderada em Niterói, tal segregação é de fato intensificada quando levamos em conta a condição dos brancos que habitam as mesmas comunidades. Esses efeitos negativos tornam-se mais intensos à medida que o tempo passa. ${ }^{26}$ 
João H. Costa Vargas. Apartheid brasileiro...

Seria prematuro expandir tais conclusões para o resto da Regiāo Metropolitana do Rio de Janeiro e, mais ainda, para o restante da nação. Padrões de espacialização de raça e pobreza ocorrem diferentemente em áreas distintas. Por exemplo, enquanto a pobreza estava concentrada nas periferias de cidades como São Paulo no período anterior à década de 1980 (Fausto, 1984; Lévi-Strauss, 1986; Rolnik, 1988), o Rio de Janeiro era diferente porque posições sociais desiguais não se traduziam em uma enorme distância espacial - ao menos não de acordo com os padrões mais ou menos ordenados de São Paulo (Kowarick, 1988). De fato, tal proximidade, que se fez ainda mais visível na geografia montanhosa da costa do Rio de Janeiro, é freqüentemente oferecida como uma explicação para os altos níveis de violência urbana e de medo da criminalidade na mídia e no imaginário popular.

Entretanto, pelo menos desde a década de 1980, parece haver uma convergência na forma como várias metrópoles brasileiras produzem padrões espaciais que expressam diferenças de classe. Análises recentes têm matizado as distinções espaciais/sociais entre o Rio e outras grandes cidades brasileiras, especialmente São Paulo.

Por um lado, trabalhos importantes conduzidos por historiadores, antropólogos e sociólogos argumentam que correspondências nítidas entre classe social e espaço urbano, tidas como características marcantes do padrão de ocupação urbana em São Paulo, onde zonas relativamente homogêneas do ponto de vista econômico correspondiam a áreas geográficas específicas (Caldeira, 1984), estão se tornando cada vez mais complexas. Ou seja, a capital paulista apresenta padrões de ocupação do solo urbano por classe social que apontam para um contexto bem mais heterogêneo e mutável (Kowarick e Ant, 1988). Nos últimos 30 anos, ademais, tais processos de heterogeneização social dentro de áreas específicas intensificaram-se. $\mathrm{O}$ aparecimento e crescimento de favelas e cortiços em áreas centrais e da zona oeste ao mesmo tempo em que condo- 
Revista de Antropologia, São Paulo, USP, 2005, v. 48 No 1.

mínios de classe média e alta pontuam crescentemente áreas periféricas até então majoritariamente pobres, exemplificam os processos de heterogeneização social e espacial (Caldeira, 2000; Vargas, 1993).

Por outro lado, análises recentes têm mostrado que, na Região Metropolitana do Rio de Janeiro, a pobreza está cada vez mais concentrada em municípios como São João de Meriti, Nilópolis e Nova Iguaçu. Neles, há uma percentagem maior de pessoas que são pobres e negras do que se verifica nos municípios mais centrais, como no Rio de Janeiro e em Niterói. Estas mesmas cidades periféricas têm apresentado taxas maiores de construçôes em lotes irregulares do que o que tem sido documentado no Rio de Janeiro e em Niterói, reforçando a noção de que há uma concentração do aumento da pobreza nas periferias da Região Metropolitana do Rio de Janeiro. Oliveira (2002, p. 12) chegou a tais conclusões baseado na análise dos dados do IBGE e da Pesquisa Nacional por Amostra de Domicílios (Pnad) para 1980, 1988 e 1992.

Um manancial de estudos históricos e contemporâneos detalha a racialização do espaço urbano no Rio. O livro Um século de favela (1999), editado por Zaluar e Alvito, ainda que não tenha o foco explícito em raça, fornece evidências sobre o número desproporcional de negras/os habitando áreas caracterizadas por falta de infra-estrutura, pobreza e uma imposta marginalização social e política (Burgos, 1999, p. 28-31). Igualmente, pesquisas sobre comunidades trabalhadoras no Rio de Janeiro confirmam a racialização do espaço urbano ao revelarem a presença majoritária de afro-brasileiros em favelas (Mendonça e Benjamin, 1997; Goldstein, 2003; Perlman, 1977; Sheriff, 2001; Zaluar, 1985, 1994).

Com base nessa evidência, em meu trabalho no Rio de Janeiro (Vargas, 2003, 2004b, 2005) e, mais importante, em análises recentes de economia política que tentam entender o papel de raça na determinação de expectativas de vida no Brasil, gostaria de sugerir quatro proposições de trabalho. Essas proposições não apenas ajudam a compreender 
João H. Costa Vargas. Apartheid brasileiro...

as reações negativas e generalizadas contra o condomínio-favela, mas auxiliam na elaboração de formulações sobre a racialização do espaço urbano no Rio de Janeiro.

Tais proposições são as seguintes: primeiro, a pobreza está conectada à raça e, mantendo-se outras variáveis sociais constantes (tais como educação, experiência profissional e idade), negras/os têm sistematicamente renda menor e menos patrimônio que brancos (Hasenbalg, 1979; Inspir, 1999; Silva e Hasenbalg, 1992). Segundo, a pobreza está relacionada ao espaço urbano - as áreas habitadas pelos pobres são aquelas onde os serviços básicos (tais como transporte, esgoto e água corrente) assim como a presença de bens de consumo duráveis (como geladeiras e fogões) estão em falta ou presentes em menor número e/ou são de pior qualidade do que aqueles existentes nos bairros de classe média e classe média-alta (Henriques, 2001). Terceiro, os padrões de ocupação do espaço urbano são influenciados por raça na mesma medida em que as áreas para as quais os pobres são relegados são desproporcionalmente ocupadas por negras/os (Oliveira, 1999, 2000, 2001). E, quarto, noções de espaço urbano influenciam entendimentos sobre raça na medida em que se espera que áreas urbanas distintas do ponto de vista de renda e classe social correspondam a grupos raciais diferentes. Daí a percepção comum no Brasil de que, se uma pessoa é moradora de favela, ele ou ela deve ser não-branco/a (Vargas, 2004b).

Uma descrição e avaliação mais precisas da terceira e quarta proposições descritas acima requerem mais trabalho de pesquisa e o desenvolvimento de um arcabouço teórico. Para concluir esta seção e seguindo a adoção por Oliveira da perspectiva de Massey e Denton para analisar processos urbanos e raciais no Grande Rio, apresento alguns conceitos, derivados da análise dos Estados Unidos, que têm o potencial de gerar uma estrutura teórica útil para aqueles que tentam compreender como no Brasil raça e espaço urbano influenciam-se mutuamente. Tais análi- 
ses necessitam ser cuidadosamente adaptadas e modificadas de maneira a refletir as singularidades das formações espacial e racial brasileiras.

De um ponto de vista histórico, o trabalho pioneiro de Sugrue (1996) é crucial na medida em que revela precisamente processos socialmente construídos e, portanto, eivados por disputas de poder, que correspondem à consolidação da ocupação do espaço urbano em Detroit, especialmente a partir da década de 1940 . Ao escrever sobre a discriminação contra as/os negras/os nas áreas de moradia, emprego e participação política, Sugrue demonstra como os brancos utilizam privilégios institucionalizados (por exemplo, acesso a emprego e financiamento federal para moradia) e ação coletiva para manter homogeneidade racial em seus locais de trabalho e de moradia. Recorrendo com freqüência à violência preventiva para proteger a pureza idealizada da mulher branca e intimidar famílias negras, impedindo-as de se mudarem para suas comunidades, os brancos representavam e atuavam no mundo social de acordo com uma geografia claramente racializada. Bairros negros e brancos não eram, assim, apenas entidades físicas, mas campos políticos cuja definição e preservação ocorriam por meio de batalhas aguçadas.

O "gueto" não era simplesmente uma construção física; era também uma construção ideológica. $\mathrm{O}$ espaço urbano tornou-se uma metáfora para as diferenças raciais percebidas. No próprio ato de definir os limites do "gueto", os brancos também continuavam a definir e reforçar os limites da raça. (Sugrue, 1996, p. 229)

O trabalho de Oliver e Shapiro (1995) oferece uma dimensão sociológica para os processos analisados por Sugrue. Esses autores demonstram como desvantagens acumuladas ao longo do tempo, especialmente quando estão relacionadas a salários reduzidos e ao valor de imóveis em bairros negros, fazem com que famílias negras, comparadas a famílias 
João H. Costa Vargas. Apartheid brasileiro...

brancas similares, sistematicamente ganhem salários menores e claramente tenham menor patrimônio. O trabalho de Oliver e Shapiro dá suporte à seguinte passagem:

Negros têm mais dificuldades para obter financiamentos habitacionais e, quando eles compram uma casa, ela é normalmente de menor valor do que uma casa comparável de propriedade de brancos. À medida que negros se mudam para um determinado bairro, os brancos deixam o lugar por temor de que o valor dos imóveis irá cair. À medida que os brancos partem, o temor se torna realidade e o preço dos imóveis diminui... Dessa forma padrōes inter-relacionados de acumulação e "desacumulação" racializados criam uma desigualdade duradoura. (Brown et al., 2003, p. 23-24)

Os processos históricos e sociais que têm criado espaços urbanos racializados nos Estados Unidos são específicos tanto da formação racial daquele país (Goldberg, 1993; Lipsitz, 1998; Massey e Denton, 1993) quanto da maneira como conflitos políticos alimentaram as imbricações mútuas entre raça e espaço urbano (Davis, 1992; Gregory, 1998; Kim, 2000; Mollenkopf, 1993; Saito, 1998).

Ainda que os estudos sobre cidades brasileiras geralmente não focalizem as possibilidades dessas interconexões cognitivas políticas e históricas entre raça e espaço urbano, gostaria de argumentar que as evidências já existem - em alguns estudos urbanos e certamente nas representações socialmente compartilhadas e veladas da mídia sobre as favelas - e revelam a riqueza de tal perspectiva analítica. Seriam comunidades pobres tão demonizadas se não fossem consideradas territórios negros? Do mesmo modo, seriam negros vistos de maneira tão negativa não fossem as representações e as políticas oficiais com relação aos lugares pelos quais eles estão super-representados, a saber, as favelas e as áreas pobres? A resposta para essas questôes depende da forma como se anali- 
sam raça e espaço urbano enquanto elementos constitutivos cruciais das hierarquias sociais profundamente desiguais no Brasil. Isso tudo é para dizer que as disparidades sociais absurdas que caracterizam cidades como Rio de Janeiro, São Paulo, Recife, Belo Horizonte e Salvador, por exemplo, referem-se tanto à racialização do mundo social quanto às formas como essa racialização torna-se codificada na geografia urbana e social das cidades.

A seguir, abordo as formas como os ativistas de favelas do Rio têm dado continuidade às suas lutas contra as injustiças racializadas que marcam seus corpos, suas vidas e seus locais de residência. ${ }^{27} \mathrm{Na}$ luta contra as representaçôes diárias negativas, a marginalização política e sua condição imposta de cidadãos de segunda classe, os militantes do Jacarezinho têm encontrado poderosos, senão surpreendentes, aliados entre ex-membros do Partido dos Panteras Negras, nos Estados Unidos. Concluo este artigo, assim, com uma avaliação dessas alianças transnacionais e uma análise de como as teorizações e práticas que emergem de tais alianças auxiliam a compreensão das realidades, mutuamente constituídas, de raça e espaço urbano.

\section{Jacarezinho e suas alianças políticas transnacionais: esperança em tempos de globalização neoliberal}

Enquanto a história dos portões e das câmeras ia se desenvolvendo com muito alarde, os militantes do Jacarezinho estavam envolvidos em um projeto mais importante. Inspirados pela Coalizão Contra o Abuso Policial - Coalition Against Police Abuse (CAPA), de Los Angeles, cujos membros vêm visitando o Jacarezinho desde 1993 e com quem os ativistas brasileiros têm estado em contato desde então (Vargas, 2003), Rumba e seus colaboradores estavam prestes a inaugurar o Centro 
João H. Costa Vargas. Apartheid brasileiro...

Zinzun. Denominado em reconhecimento a Michael Zinzun, o exmembro do Partido dos Panteras Negras, fundador e coordenador do CAPA havia visitado e estava em constante diálogo com os militantes do Jacarezinho. O Centro iria funcionar como um lugar onde membros da comunidade teriam a infra-estrutura necessária para denunciar casos de brutalidade policial e obter assistência jurídica. Da mesma forma como havia sido feito em Los Angeles desde 1976, quando a CAPA foi fundada, os vários casos de má conduta policial no Jacarezinho serviriam como base para a organização não apenas contra a represssão policial, mas como forma de protesto contra os vários problemas sociais e econômicos que afligem a comunidade. ${ }^{28}$ Documentar, interpretar e pressionar as autoridades estatais para reconhecer e remediar tais casos: esses constituíam os objetivos principais do Centro Zinzun. Embora o Brasil não tenha a pena de morte institucionalizada, os moradores de favelas sempre souberam que sentenças de morte e execuções sumárias, in loco, são aspectos constitutivos do papel da polícia - aspectos que são, ao menos tacitamente, sancionados pela sociedade em geral. ${ }^{29}$ Ao disseminar a informação sobre a brutalidade policial na comunidade e ao facilitar encontros, marchas e protestos, membros da Associação de Moradores esperavam criar fatos políticos que se traduziriam em maior conscientização dentro e fora da comunidade, pressionando assim o aparato do Estado para remediar as injustiças, desafiar a opinião pública - especialmente aquela expressa em veículos da grande mídia, como O Dia, a Fotha de S.Paulo e a Rede Globo - e prevenir mais atos de brutalidade.

Uma nota sobre o Centro Zinzun apareceu na mesma matéria de O Dia sobre a favela-condomínio. Intitulada "Pantera Negra orienta projeto", ${ }^{30}$ a nota criminalizou a instituição de forma bastante direta: o centro foi irrefutavelmente ligado aos mesmos ativistas que, supostamente, estavam protegendo os traficantes de drogas enquanto se opunham à polícia. Que o centro estava recebendo o nome de um ex-Pantera Negra 
Revista de Antropologia, São Paulo, USP, 2005, v. 48 No 1.

apenas confirmou o caráter criminoso do empreendimento. Não foi supresa, assim, que agentes policiais disfarçados começaram a prestar ainda mais atenção em todos nós, envolvidos na iniciativa, após essa publicação em $O$ Dia. Não teria havido necessidade de intimidação se nossas atividades não fossem vistas como ameaçadoras ou mesmo criminais. ${ }^{31}$ Além do mais, nenhuma dessas reações negativas teria acontecido caso se instalassem os portões e o Centro Zinzun em bairros que não fossem favelas. Todos esses elementos demonstram como raça e espaço urbano produzem uma combinação deveras inflamável, particularmente quando moradoras/res negras/os de comunidades marginalizadas não somente demandam cidadania plena, mas, ao fazê-lo, questionam sua desumanização sistemática pelo Estado, pelas elites e pela opinião pública mais ampla.

Exclusão residencial foi um tema central nos debates que se seguiram entre ativistas do Rio e de Los Angeles. Afro-americanos são deveras familiarizados com os efeitos negativos da segregação racial - suas vidas são irremediavelmente marcadas por tal realidade. Eles destacaram com freqüência que o Jacarezinho em muito se assemelhava a seus bairros: guetos e favelas são caracteristicamente marcados por ocupação da polícia militarizada, presença de traficantes de drogas, pobreza, mortes prematuras em quantidade, moradias precárias, aluguéis caros e preços altos para produtos alimentícios, desespero generalizado e, acima de tudo, presença massiva de negras/os. A princípio, no entanto, a maioria das pessoas no Jacarezinho envolvidas nessas conversas não perceberam a importância da raça. Algumas, de fato, questionaram a própria negritude e repetidamente expressaram seu desconforto com a idéia de afirmá-la e ter orgulho dela. Quando os ex-Panteras Negras e os líderes mais politizados da favela tentaram discutir as razóes para a massiva presença de negras/os em lugares como o Jacarezinho, aqueles que relutavam em entender as implicações da raça apontavam que havia muitos brancos 
João H. Costa Vargas. Apartheid brasileiro...

na comunidade. $\mathrm{O}$ mesmo aconteceu quando o tópico de discussão foi o abuso policial, a discriminação no emprego e os serviços precários de saúde e educação disponíveis na área. Nos encontros semanais a que compareci entre junho e agosto de 2001, nos quais representantes de cerca de 70 favelas tentavam se organizar em nível municipal (Vargas, 2003), resistência similar ao reconhecimento das implicações raciais da realidade da favela ocorria com freqüência.

Ainda assim, o próprio fato de tais discussões acontecerem é um forte indicador de mudanças em curso na forma como comunidades negras e pobres pensam e se organizam. A busca de autodefinição, autonomia e uma agenda política correspondente: essas orientaçóes marcavam aquele momento de maneira contundente. Enquanto seria imprudente afirmar uma crescente conscientização racial generalizada entre ativistas e moradores do Jacarezinho, é indubitável que existe uma aceitação geral da idéia de que as injustiças sociais que caracterizam suas comunidades precisam ser abordadas e expressas para um cenário político mais amplo. Raça, espaço urbano e classe social, entre outros tópicos de discussão, oferecem categorias analíticas através das quais os absurdos do cotidiano de comunidades negras e pobres, assim como estratégias de organização autônoma, podem emergir. A aliança com militantes negras/os dos Estados Unidos tem-se provado importante não porque afroamericanos fornecem modelos que devem ser imitados de forma acrítica, mas principalmente porque os ex-Panteras Negras são capazes de estimular discussóes que tocam em aspectos fundamentais da estrutura social brasileira. Em um contexto nacional marcado pela hiperconsciência de raça e sua concomitante negação, ${ }^{32}$ é crucial que a onipresença da raça seja discutida enquanto seu silenciamento e sua negação não menos perniciosos sejam constantemente desafiados. Os ativistas do Jacarezinho e dos Estados Unidos já estão produzindo resultados concretos na medida em que a racialização do espaço urbano, a espacialização das 
Revista de Antropologia, São Paulo, USP, 2005, v. 48 no 1.

relações raciais e as possibilidades de uma política de resistência transnacional são centrais em seus diálogos e sua colaboração.

Os efeitos políticos e simbólicos das alianças com ex-Panteras Negras sobre a polícia, os políticos e os traficantes de drogas não podem ser subestimados. Por causa de sua reconhecida história de confronto contra a polícia em particular e as instituiçóes opressoras em geral, os militantes da CAPA oferecem aos brasileiros uma vantagem tática na medida em que incorporam uma tradição que se tem provado efetiva na luta contra as formas institucionalizadas de poder. Além de resultados práticos bastante palpáveis, o contato com os militantes negros americanos gerou otimismo e confirmou a vontade dos afro-brasileiros de continuar na luta. ${ }^{33}$

O combate ao abuso da polícia militarizada concentrada nas favelas constitui, então, uma estratégia para abordar a constelação de desvantagens sociais acumuladas que negras/os enfrentam no Brasil. A brutalidade policial é o resultado concreto, muitas vezes letal, de como raça e espaço urbano se cristalizam nas representações dominantes. Enquanto o objetivo principal e original da CAPA é dar assistência legal às vítimas da brutalidade policial, a instituição considera que o abuso policial é parte de um contexto mais amplo de opressão. Seus membros vêem sua luta contra a brutalidade policial necessariamente conectada às desigualdades estruturais e históricas mais amplas. A luta contra a brutalidade policial, dessa forma, é parte da luta maior pela justiça social. ${ }^{34}$

É precisamente essa abordagem sistemática que os ativistas do Jacarezinho estão adotando na medida em que os planos para o Centro Zinzun estão sendo desenvolvidos. Enquanto os obstáculos no caminho da realização desse projeto parecem enormes, as alianças transnacionais que se desenvolvem em meio à colaboração entre negras/os do Rio de Janeiro e de Los Angeles têm encarado esses desafios. Nesse processo, são geradas novas ferramentas políticas e possibilidades organizacionais. Tudo se dá 
no bojo do processo de globalização que, paradoxalmente, também tem contribuído para expandir e intensificar a marginalização de populações historicamente racializadas e excluídas (Barlow, 2003; Bello, 2003; Sivanandan, 2003). As críticas contundentes elaboradas por esses ativistas sobre a dinâmica entre raça e espaço urbano que consolida formas históricas de marginalização contra as/os negras/os da diáspora africana - ainda que precisem de análises mais variadas que incorporem gênero, sexualidade e idade, apenas para listar algumas variáveis fundamentais - já têm produzido ângulos estratégicos a partir dos quais podemos efetivamente resistir e nos opor aos piores efeitos das formas locais e transnacionais de exclusão racializada.

\section{Notas}

1 Agradecimentos a George Lipsitz pela inspiração inicial para estas reflexôes, que se beneficiaram de sua legendária e, de fato, verdadeira generosidade. Quando perspectivas de trabalho pareciam difíceis, ele providenciou para que eu ministrasse um de seus cursos na Universidade da Califórnia em San Diego, em 1999. Sua ementa para a aula "Políticas de etnicidade na América", adotada por mim sem adaptação e sem cerimônia, enfatizava as ligações mútuas entre raça e espaço urbano. Aos ativistas no Rio e em Los Angeles que não têm outra escolha a não ser resistir, agradeço por compartilharem sua sabedoria e coragem. Obrigado também a Jacqueline Pólvora, por importantes sugestôes bibliográficas. Agradeço a Athayde Motta pela tradução. Sou grato aos professores Edmund T. Gordon e Omi Osun Olomo, diretores do Center for African and African American Studies, na Universidade do Texas em Austin, que não hesitaram em providenciar apoio financeiro de última hora para a tradução. Marcia Fingal, obrigado.

2 Enquanto o jornal $O$ Dia alegava que Rumba teria dito que as câmeras haviam sido compradas com recursos de ONGs (Braga, 2001, p. 4), a Folha de S.Paulo trazia declarações de Gabriel de que as câmeras haviam sido "doadas por um grupo 
de ciganos" (Petry, 2001, p. C1). Utilizo a última versão por ser a que escutei dos próprios ativistas.

3 Ribeiro e Telles (2000) mostram que 70\% da população residente em favelas do Rio de Janeiro em 1991 era negra (preta e parda).

4 No contexto brasileiro, considero "negra/o" com um significado racial e não apenas de cor. Com base em trabalho etnográfico em uma favela no Rio de Janeiro, Sheriff (2001, p. 45) argumenta que, para muitos dos habitantes dessas comunidades pobres, enquanto existem vários termos para descrever a aparência de alguém, há apenas duas verdadeiras categorias raciais: negra e branca. Estou a par do debate entre aqueles que defendem a singularidade das relaçôes raciais no Brasil (principalmente com relação às dos Estados Unidos) e aqueles que estão tentando desenvolver um arcabouço analítico a partir do qual as correspondências entres as duas formaçōes raciais se tornariam visíveis. Para tanto, ver, por exemplo, o diálogo entre, de um lado, Hanchard (2002), e de outro, Bourdieu e Wacquant (1999). Estes dois últimos acusam o primeiro de superimpor o entendimento racial dos Estados Unidos à realidade brasileira, desse modo interpretando erroneamente a dinâmica social do Brasil. No entanto, Bourdieu e Wacquant, ao criticarem a "razão imperialista americana" de Hanchard, produzem um problema análogo ao que detectam em Hanchard. Isso porque os autores propõem uma solução eminentemente francesa como alternativa aos erros que eles vêem em Hanchard. Ademais, a ignorância de Bourdieu e Wacquant sobre a realidade social brasileira foi lembrada por vários analistas envolvidos nessa controvérsia (French, 2003). A minha posição (Vargas, 2003, 2004b) é a seguinte: há um excesso de informação que pode ser captada a partir de um engajamento com a história, crítica e análise das relações raciais nos Estados Unidos. Essa informação é importante não porque ela fornece parâmetros que devem ser seguidos cegamente, mas porque ela nos dá uma dimensão das possibilidades e armadilhas contidas nas formas estratégicas de solidariedade racial. Para outras leituras que abordam aspectos desse debate, e em particular as possibilidades práticas e teóricas que uma comparação crítica do Brasil e dos Estados Unidos gera, ver Cunha (1998), French (2000), Fry (1995), Segato (1998) e Silva (1998).

5 Pesquisa por amostragem em todo o País conduzida pela Folha de S.Paulo/Datafolha (1995, p. 13) revelou que, enquanto $89 \%$ dos brasileiros entrevistados disseram que havia racismo no País, apenas 10\% admitiram ser racistas. A mesma pesquisa, 
entretanto, concluiu, a partir das análises das respostas no questionário, que 87\% das/dos não-negras/os revelavam alguma forma de preconceito (p. 17). Um dos problemas dessa pesquisa é a sua recusa em discutir o conceito de raça e como este se relaciona com a enorme variedade de categorias de cor. Tal dinâmica, em que a conscientização sobre raça é ao mesmo tempo predominante e reprimida, conforma o que eu tenho chamado em outros textos de hiperconsciência de raça e sua negação, de acordo com que categorias racias de fato protegem e perpetuam o mito da democracia racial (Vargas, 2004b).

6 A postura preventiva da polícia com relação às comunidades negras encontra paralelos nos Estados Unidos, especialmente - mas, certamente, não apenas - em momentos de desordem social (Gooding-Williams, 1993; Miller, 1996). Sobre os assassinatos cometidos pela polícia do Rio de Janeiro em favelas, e o aparente apoio que tais atos recebem da população em geral, ver Human Rights Watch/Americas (1997) e Mitchell e Wood (1998).

7 Enquanto espaço e lugar podem, de fato, ser definidos mutuamente (Grossberg, 1992; Tuan, 1977), lugar indica a área mais imediata estabelecida por interações sociais específicas distintas do espaço urbano mais amplo e impessoal que delinea vários outros lugares.

8 A história de Rumba Gabriel oferece uma perspectiva sobre os desafios que ativistas comunitários negras/os críticas/os à polícia e aos traficantes de drogas enfrentam. Rumba esteve temporariamente sob asilo nos Estados Unidos quando ameaças à sua vida tornaram-se mais intensas no Rio. No Centro de Estudos Africanos e AfroAmericanos, no Departamento de Antropologia, e no Instituto de Estudos LatinoAmericanos da Universidade do Texas, Rumba teve tempo para refletir e discutir sua experiência com companheiros, ativistas negras/os do Brasil, entre os quais Diva Moreira, Athayde Motta e Joel Zito Araújo, além de estudantes e acadêmicos que atuam como ativistas. Pouco após seu retorno ao Brasil, em janeiro de 2002, Rumba foi preso com base em acusações de envolvimento com o tráfico de drogas em uma das várias batidas policiais conduzidas pelo governo do estado do Rio de Janeiro. Devido à ausência de provas e à pressão de um movimento amplo que incluía organizações e indivíduos comprometidos no Brasil e nos Estados Unidos, Rumba foi solto em fins de 2002 depois de ir a julgamento e do caso ser arquivado. Em outra batida policial, em 2003, seria detido novamente, com o famoso cantor Belo, que optou por não se entregar à polícia. Mais uma vez, após meses de 
encarceramento e audiências, Rumba foi solto por falta de provas sobre seu suposto envolvimento com o tráfico de drogas. Essa história, cujos detalhes merecem uma análise mais profunda e mais cuidadosa, ilustra os enormes obstáculos que os ativistas de favelas devem enfrentar quando suas opções políticas não se adaptam aos modelos clientelistas e corruptos de praxe.

9 Alguns estudiosos de favelas, seguindo um padrão que é, de fato, a norma entre acadêmicos e funcionários públicos no Rio, estabelecem rapidamente conexões entre ativistas e traficantes. Por exemplo, Arias (2004, p. 8) escreve: "Nas favelas do Rio, onde grupos criminais têm fortes conexôes com alguns líderes comunitários e representantes do governo...”. Goldstein (2003) é mais atenta ao papel da polícia no controle das favelas e como esta e os traficantes trabalham freqüentemente de forma combinada. Trabalhos pioneiros de Zaluar $(1985,1994)$ chamaram atenção para essas conexôes.

10 Clippings de jornais do Rio entre dezembro de 1990 e setembro de 2003 estão repletos de descrições de extorsōes, raptos e espancamentos com mortes e tiroteios - todos realizados com participação da polícia e, em sua maior parte, contra pessoas de ascendência africana. Meu primeiro dia no Rio em 2001 foi gasto protestando contra outra dessas mortes. Um jovem havia levado um tiro na nuca enquanto estava sentado ao lado da namorada na varanda de sua casa na Favela do Andaraí. O jovem era um estudante exemplar e trabalhava. Seu pai estava em estado de desespero e desolação. As mais de mil pessoas presentes à manifestação reuniram-se em uma manhã fria de julho no Largo do Machado, e, de lá, marchamos para a residência oficial do governador do Rio de Janeiro (à época Anthony Garotinho) nas Laranjeiras, a poucos quilômetros de distância. Como de costume, havia rumores de envolvimento de traficantes de drogas na manifestação. Mas Rumba e outros líderes de associações de moradores, com políticos como Jurema Batista, vereadora pelo Partido dos Trabalhadores, garantiram que o espírito e o público da marcha - a maioria jovens moradores de várias favelas - fossem comunicados aos setores no poder e à mídia. Listar e analisar todos esses casos de má conduta e brutalidade policial seriam parte de um outro estudo, que estou começando a realizar. Os artigos de jornais coletados para esse ensaio incluem matérias do O Dia, Extra, O Globo e Jornal do Brasil - os maiores diários no Rio - assim como material do Inverta, um semanário socialista, e do Viva Favela, um website dedicado aos problemas dessas comunidades no Rio de Janeiro. 
João H. Costa Vargas. Apartheid brasileiro...

11 O ponto alto da desmoralização da polícia carioca aconteceu em 19 de julho de 2001, quando imagens de um grupo de policiais recebendo dinheiro de traficantes na Favela do Morro da Providência foram transmitidas no horário nobre e em cadeia nacional pelo amplamente assistido Jornal Nacional. "Em tempos de guerra, os policiais corruptos teriam sido executados", declarou o comandante-geral da Polícia Militar Wilton Ribeiro. Suas palavras, impressas em letras garrafais, estavam na primeira página de $O$ Dia, de 20 de julho de 2001, ao lado de fotos dos policiais recebendo dinheiro dos traficantes.

12 Wilson Aquino, "Cidade do Medo (Jacarezinho Especial)", O Dia, 4 de junho de 1999, p. 16.

13 Nas décadas de 1950 e 1960, o mito da democracia racial estava sendo algo questionado pela pesquisa etnográfica financiada pela Organização das Nações Unidas para a Educação, a Ciência e a Cultura (Unesco). Estudos produzidos por Roger Bastide e Florestan Fernandes (1955), por Fernando Henrique Cardoso e Octavio Ianni (1960), assim como por Marvin Harris (1956), Harry Hutchinson (1957) e Charles Wagley (1952) enfatizaram o papel da raça na produção de desigualdades sociais. Ainda assim, o mito permaneceu na medida em que esses trabalhos tendiam a (a) acentuar classe social como o determinante final das hierarquias sociais e (b) prever a resolução das diferenças raciais como um epifenômeno do inevitável desenvolvimento das relaçóes sociais de cunho capitalista em direção ao socialismo. Ou seja, na marcha da história, o racismo desapareceria com as desigualdades de classe. Essa questão, em especial, aparece de forma clara em Fernandes (1965, 1972). Somente na década de 1970, em um momento em que as demandas por direitos civis nos Estados Unidos começaram a ecoar no Brasil e a ditadura militar iniciava uma lenta retração na sociedade, o racismo brasileiro e a centralidade da raça no espaço político foram inicialmente conceitualizados e questionados (Hasenbalg, 1979; Nascimento, 1977, 1989). O Partido dos Trabalhadores, a despeito de inúmeras - e freqüentemente admiráveis - tentativas de institucionalizar políticas anti-racistas, ainda está tentando lidar com os desenvolvimentos teóricos mais recentes.

14 Desde o começo do século 20, o relacionamento entre as favelas, por um lado, e as igrejas e as administraçôes públicas (tanto locais como estaduais), por outro, tem sido marcado por tentativas sucessivas destes últimos de assegurar o controle sobre as organizações de favela. Tais tentativas incluem planos para erradicar as fave- 
las, cooptar lideranças locais e transformar esse espaço em bairros por meio da provisão de infra-estrutura e serviços públicos. Rompimentos importantes ocorreram em 1957 e em 1963. Em 1957, trabalhadores que moravam na favela organizaram a Coligação dos Trabalhadores Favelados do Distrito Federal; em 1963, moradores de favela criaram a Federação das Associaçóes de Favelas do Estado da Guanabara (Fafeg). Ver Burgos (1999, p. 33). O Jacarezinho foi formalmente transformado em um bairro pela Lei Estadual 35/1992. No entanto, a decisão "não trouxe quaisquer benefícios ao lugar. Ninguém sabe ao certo quantas casas existem na comunidade e menos ainda quantas pessoas vivem na segunda maior favela do Rio" (O Dia, 4 jun. 1999, p. 16).

15 Benedita da Silva, negra nascida em uma favela no Rio de Janeiro, já foi senadora e vice-governadora do estado do Rio de Janeiro. Membro do Partido dos Trabalhadores desde sua fundação, no começo dos anos 1980, ela iniciou sua carreira política na favela Morro do Chapéu Mangueira durante as décadas de 1950 e 1960. Sua autobiografia é importante fonte de informação com relação à repressão militar que começou em 1964. Ver Mendonça e Benjamin (1997, p. 52).

16 Ver Zaluar (1985, p. 66), Mendonça e Benjamin (1997, p. 53). Não se deve ignorar o fato de que havia, com certeza, homens e mulheres favelados que desejavam sair das favelas e, por meio de programas governamentais, tornar-se proprietários de suas casas - ver Perlman (1977). Entretanto, minha questão é trazer à tona as medidas autoritárias dramáticas tomadas pelos militares e seus efeitos negativos nos esforços de organização das favelas. Não apenas as remoções contribuíam para aumentar as dificuldades financeiras de uma família - especialmente quando os novos projetos residenciais eram distantes do local de trabalho ou localizados em áreas onde novos empregos eram difíceis de ser encontrados -, mas também destruíram efetivamente as redes sociais que dependiam do espaço compartilhado das favelas. Uma vez que a relocação era baseada em renda e não no lugar de origem, a maioria dos novos projetos residenciais eram formados por pessoas que não se conheciam anteriormente. Ainda assim, conforme mostram alguns estudos, os moradores desses novos projetos residenciais, eventualmente, construíram novas redes sociais, escolas de samba, associaçôes de moradores e times de futebol. Cidade de Deus, um dos maiores projetos desse tipo, é um caso exemplar. Ver Zaluar (1985, p. 71). 
17 Para um estudo clássico da manipulação de relações clientelistas entre os pobres no Rio de Janeiro, ver Zaluar (1985). Conferir também Mendonça e Benjamin (1997, p. 54).

18 O papel que a mídia teve na consolidação da imagem dos moradores das favelas como seres racializados, cruéis e desumanos deve ser devidamente enfatizado. Com foco em determinados indivíduos, a imprensa e o noticiário da TV alimentaram e expandiram os temores que eram cada vez mais associados com a "guerra às drogas". Por exemplo: Buzunga, um jovem negro com pouco mais de 20 anos em meados da década de 1980, foi mostrado com seu rifle automático e alguns pacotes de cocaína amarrados na cintura enquanto se vangloriava dos assassinatos, das aventuras sexuais e do controle geral que tinha sobre a Favela da Rocinha. Eventualmente, foi assassinado por traficantes rivais. Considerações históricas e estruturais, obviamente, estavam ausentes da versão da mídia sobre o que ocorria nas favelas. O volume de cocaína sem precedentes disponível no Rio de Janeiro estava relacionado à reconfiguração do mercado global resultante da repressão ao comércio de drogas e suas redes de apoio nos Estados Unidos (http://www.starnews2001. com.br/drogas.html, 2000). Ver também Webb (1999).

19 Robinson (1998-1999) fornece uma análise perspicaz do impacto das políticas de globalização neoliberal nos países latino-americanos. $\mathrm{O}$ autor conecta de maneira convincente o novo modelo de globalização com um aumento de desigualdade, polarização, empobrecimento e brutalidade policial no Brasil.

20 Para uma seleção de ensaios pioneiros sobre economia política, representações populares e perspectivas das favelas e projetos residenciais no Rio de Janeiro, ver Zaluar (1994).

21 No Jacarezinho, por exemplo, estima-se que aqueles envolvidos com o tráfico de drogas não excedem 100 pessoas. Considerando que o Jacarezinho tem uma população de mais de 150 mil pessoas, a proporção dos envolvidos com drogas é de $0,07 \%$.

22 Para uma análise das motivaçoes políticas por detrás da Operação Rio, ver Soares (1996).

23 Ver Human Rights Watch/Americas (1997, p. 33).

24 Nascimento (1989), Munanga (1999), Guimarães (1999) e D’Adesky (2001), entre outros, têm comentado sobre esse assunto. 
25 Maior tempo de residência na favela é tido aqui como sinal de mobilidade social decrescente.

$26 \mathrm{O}$ mesmo fenômeno foi percebido na pesquisa de doutorado de Jacqueline Britto Pólvora em uma favela de Porto Alegre, onde ela notou que negras/os, quando comparados aos brancos, ocupam sistematicamente as piores e mais isoladas residências, têm os empregos de menor salário e maior instabilidade, e têm mais problemas de saúde e menos acesso aos orgãos de saúde pública.

27 Gilliam (1992) e Goldstein (2003, p. 120-35) descrevem como gênero, sexualidade e raça se inter-relacionam. Essas intersecções múltiplas servem como expressões das hierarquias sociais profundamente desiguais no Brasil (além de permitir que estas sejam visualizadas) e dos obstáculos correspondentes que previnem a conscientização racial entre negras/os e negras/os pobres.

28 Em 1979, após descobrir que a CAPA havia sido infiltrada por agentes policiais, seus membros, com membros de outras organizaçôes progressistas que também haviam detectado e documentado a presença de espiōes em suas sedes, processaram a polícia de Los Angeles por violação de seus direitos constitucionais à organização, à privacidade e à associação. Assistidos juridicamente por advogados e pessoal da American Civil Liberties Union (ACLU), em 1983, as 131 vítimas aceitaram um acordo no valor de 1,8 milhão de dólares. As vítimas também impuseram uma lista de nove resoluçóes para a burocracia municipal e o Departamento de Polícia de Los Angeles. Foi acordado que a Corte Suprema da Califórnia teria jurisdição sobre a sentença, regulando e sendo garantia, portanto, contra espionagens futuras. Em 1986, após ser espancado por policiais em Pasadena e perder a visão em um dos olhos, Zinzun foi indenizado em 1,2 milhão de dólares. Em julho de 1994, ele recebeu cerca de 500 mil dólares após uma disputa com o segundo nome na hierarquia do Departamento de Polícia de Los Angeles, o chefe-assistente Robert L. Vernon. Enquanto Zinzun fazia campanha para o Board of City Directors de Pasadena, em 1989, Vernon o acusou de atos terroristas. Para uma análise dos vários processos de membros da CAPA contra o Departamento de Polícia de Los Angeles, ver Vargas (1999).

29 É curioso que, embora 76\% das pessoas pesquisadas no Rio de Janeiro e em São Paulo acreditem que policiais participem ativamente nos esquadróes da morte (Human Rights Watch/Americas, 1997), existe pouco (ou quase nenhum) apoio para organizações e eventos que protestem contra a brutalidade policial que não 
venha das favelas. Uma possível conclusão a ser retirada disso é que, enquanto se reconhece a brutalidade da polícia, existe também a consciência de que essa mesma brutalidade é um apoio necessário e vital para as hierarquias sociais e raciais.

30 Em vez de se referir a Zinzun, entretanto, o "Pantera" cuja fotografia apareceu imediatamente abaixo do título era eu. Enquanto o resto do artigo estava correto na descrição de minha ocupação como antropólogo, minha colaboração atual com a CAPA, as origens dessa organização com os Panteras Negras e uma descrição breve de como os Panteras ofereceram resistência armada contra a opressão policial (O Dia, 8 jul. 2001, p. 4), o prejuízo estava feito. Daquele dia em diante, haveria um carro de passeio da polícia em frente ao lugar em que estava hospedado, na zona oeste da cidade, a maior parte do dia. Curiosamente, a mesma pessoa que estava sentada impassivamente no carro estaria invariavelmente esperando por mim cada vez que eu tinha um encontro com um dos ativistas no Centro. Salvo por um incidente risível no aeroporto na minha volta para aos Estados Unidos, quando o mesmo agente tentou impedir meu embarque alegando que eu não havia passado pela inspeção de segurança, nada mais aconteceu além da óbvia intimidação passiva. Todos os ativistas da favela a quem relatei o fato não tinham dúvidas de que o carro e o agente eram parte da Polícia Civil. Eles também me instruíram a procurar assistência na Polícia Federal se o agente tentasse me intimidar. Segui o conselho deles durante o incidente no aeroporto. Sob meu pedido, um oficial da Polícia Federal confrontou o agente e a guarda de segurança que, sob pressão, ainda tentava dizer que não se lembrava de ter inspecionado meus pertences. Na presença do agente da Polícia Federal, entretanto, a memória da guarda foi refrescada, por assim dizer, e me permitiram embarcar no vôo de volta aos Estados Unidos. Em vez de exemplificar a natureza não-corrupta da Polícia Federal em relação às Polícias Civil e Militar na cidade, esse incidente revelou como a Polícia Federal não está, por definição, tão envolvida em conflitos municipais e disputas de poder. Esse fato era de conhecimento dos militantes do Jacarezinho, daí o conselho efetivo que me foi dado.

31 Na matéria de página inteira sobre a favela-condomínio, O Dia incluiu uma fotografia grande e um artigo sobre o uso de portôes em condomínios de elite. A estratégia da narrativa foi justapor legalidade e ilegalidade. Essa justaposição pode, obviamente, ser estendida a pobres/não-pobres, brancos/negras/os, favela/não-fa- 
vela, cidadão/não-cidadão e humanos/não-humanos. Os argumentos defendidos neste ensaio desenvolvem essas justaposiçōes.

32 Inspirado pelos estudos críticos das relações raciais brasileiras (Araújo, 2000; D’Adesky, 2001; Da Matta, 1981; Dzidzienyo, 1971; Gilliam, 1992; Guimarães, 1999; Hanchard, 2002; Hasenbalg, 1998; Munanga, 1999; Nascimento, 1989; Telles, 1999; Twine, 1998), desenvolvo esse conceito em Vargas (2004).

33 A luta que se torna clara tanto para os ativistas americanos quanto para os brasileiros é contra os assaltos multifacetados às/aos negras/os da diáspora africana nas Américas. $\mathrm{O}$ abuso policial e a segregação residencial são apenas duas das muitas formas de opressão que marginalizam, desumanizam e matam homens e mulheres negras/os em números desproporcionais. A Pesquisa Nacional por Amostra de Domicílios (Pnad) de 1996 apontou que, na Região Sudeste, a mais rica do País, enquanto a mortalidade infantil entre os brancos era de 25,1 por mil nascidos vivos, para as/os negras/os a taxa era de 43,1. No País como um todo, enquanto somente cerca de $50 \%$ dos domicílios ocupados por negras/os estavam conectados à rede de esgoto, a taxa era de 73,6\% para aqueles ocupados por brancos. O Índice de Desenvolvimento Humano (IDH) das Naçôes Unidas, um indicador de qualidade de vida que vai de 0 a 1 , é de 0,796 para a população brasileira como um todo, mas de 0,573 para as/os negras/os brasileiras/os (Henriques, 2001). Disparidades salariais confirmam a desigualdade entre negras/os e brancos. $\mathrm{Na}$ Região Metropolitana de São Paulo, negras/os ganham em média R \$ 2,94 por dia, enquanto os brancos ganham R\$ 5,50 por dia (Inspir et al., 1999, p. 39). Todos os dados econômicos e sociais revelam que "não-brancos estão sujeitos a um 'processo de desvantagens cumulativas' em suas trajetórias sociais" (Hasenbalg \& Silva, 1999, p. 218) que bloqueia sua mobilidade social. Os brancos, por outro lado, são claramente mais bem-sucedidos em alcançar mobilidade social crescente. O processo é similar, de forma reveladora, ao que acontece nos Estados Unidos, conforme evidenciado, por exemplo, por Oliver e Shapiro (1995), e Brown et al. (2003).

34 "A CAPA vê não apenas a necessidade de se organizar contra o abuso policial, mas também a necessidade de ligar o aumento do abuso policial ao aumento da crise econômica que está atualmente ocorrendo nos Estados Unidos. Em outras palavras, se os trabalhadores fizerem greve por melhores salários, quem é chamada? A polí- 
cia. Se você não pode pagar seu aluguel e se recusa a ir para o meio da rua, quem é chamada? A polícia. E se você organiza atos contra um sistema corrupto e injusto, quem é chamada? A polícia, seja com a força bruta ou com espiōes disfarçados. A CAPA acredita que a polícia é um elemento necessário para a manutenção de um sistema controlado por poucos milionários e políticos que colocam o lucro à frente do povo" (Relatório do CAPA, 1989-1993, n.d.).

\section{Bibliografia}

\section{ADORNO, Sérgio}

1995

"Discriminação racial e justiça criminal em São Paulo", Novos Estudos Cebrap, 43: 46-63.

AMAR, Paul

"Reform in Rio: reconsidering the myths of crime and violence", NACLA, Report on the Americas, 37(2): 37-42.

ARAÚJO, Joel Zito

2000 A negaçãa do Brasil: O negro na telenovela brasileira, São Paulo, Senac.

ARIAS, Henrique Desmond

2004 "Faith in our neighbors: networks and social order in three brazilian favelas", Latin America Politics \& Society, 46(1): 1-37.

BARLOW, Andrew

2003 Between fear and hope: globalization and race in the United States, Lanham, MD, Rowman \& Littlefield.

BASTIDE, Roger \& FERNANDES, Florestan

1955 Relações raciais entre preto e branco em São Paulo, São Paulo, Cia. Editora Nacional.

BELLO, Walden

"Global capitalism versus global community", Race \& Class, 44(4): 63-71. 
BOURDIEU, Pierre \& WACQUANT, Loic

1999 "On the cunning of imperialist reason", Theory, Culture, and Society, 16(1): 41-58.

BRAGA, Elcio

2001

"Favela trancada a cadeado", O Dia, 8/7.

BROWN, Michael K. et al.

2003 Whitewashing Race: The Myth of a color-blind society, Berkeley, University of California Press.

BURGOS, Marcelo Baumann

1999 "Dos parques proletários ao favela-bairro: as políticas públicas do Rio de Janeiro", in ZALUAR, Alba \& ALVITO, Marcos (eds.), Um século de favela, Rio de Janeiro, Fundação Getúlio Vargas.

CALDEIRA, Teresa P. R.

1984 A politica dos outros, São Paulo, Brasiliense.

2000 City of walls: crime, segregation, and citizenship in São Paulo, Berkeley, University of California Press.

CANO, Ignácio

1997 Letalidade da ação policial no Rio de Janeiro, Rio de Janeiro, ISER.

CARDOSO, Fernando Henrique \& IANNI, Octavio

1960 Cor e mobilidade social em Florianópolis, São Paulo, Cia. Editora Nacional.

CUNHA, Olívia Maria Gomes da

1998 "Black movements and the 'politics of identity' in Brazil", in ALVAREZ, S.; DAGNINO, E. \& ESCOBAR, A. (eds.), Culture of politics, politics of culture: re-visioning latin american social movements, Boulder, CO, Westview.

D'ADESKY, Jacques

Pluralismo étnico e multiculturalismo: racismos e anti-racismos no Brasil, Rio de Janeiro, Pallas. 
João H. Costa Vargas. Apartheid brasileiro...

DA MATTA, Roberto

1981 "Digressão: a fábula das três raças, ou o problema do racismo à brasileira", in Relativizando: uma introdução à antropologia social, Petrópolis, Vozes.

DAVIS, Mike

1992 City of quartz: excavating the future in Los Angeles, New York, Vintage.

DONZIGER, Steven (ed.)

1996 The real war on crime, New York, HarperPerennial.

DZIDZIENYO, Anani

1971 The position of blacks in brazilian society, London, Minority Rights Group.

FAUSTO, Boris

1984 Crime e cotidiano: a criminalidade em São Paulo (1880-1924), São Paulo, Brasiliense.

FERNANDES, Florestan

$1965 \quad$ A integração do negro na sociedade de classes, São Paulo, Dominus e Edusp.

1972 O negralo no mundo dos brancos, São Paulo, Difel.

FOLHA DE S.PAULO/DATAFOLHA

1995 Racismo cordial: a mais completa análise sobre o preconceito de cor no Brasil, São Paulo, Ática.

FOUCAULT, Michel

1980 Power/knowledge: selected interviews and other writings, 1972-1977, New York, Pantheon.

FRENCH, John

2000 "The missteps of anti-imperialist reason: Bourdieu, Wacquant, and Hanchard's Orpheus and Power", Theory, Culture, and Society, 107: 128.

2003 "Translation, diasporic dialogue, and the errors of Pierre Bourdieu and Loic Wacquant", Nepantla: Views from the South, 4(2): 375-89.

FRY, Peter

1995 "Why Brazil is Different", Times Literary Supplement, 8 dez., P. 6-7. 
Revista de Antropologia, São Paulo, USP, 2005, v. 48 No 1.

GILLIAM, Angela

1992

"From Roxbury to Rio - and back in a hurry", in HELWIG, D. (ed.). African-american reflections on Brazil's racial paradise, Philadelphia, Temple University Press.

GOLDBERG, David Theo

1993 Racist culture: philosophy and the politics of meaning, Cambridge, MA, Blackwell.

GOLDSTEIN, Donna M.

2003 Laughter out of place: race, class, violence, and sexuality in a Rio Shantytown, Berkeley, University of California Press.

GOODING-WILLIAMS, Robert (ed.)

1993 Reading Rodney King/Reading Urban Uprising, New York, Routledge.

GORDON, Edmund

1998 Disparate diasporas: identity and politics in an african-nicaraguan community, Austin, University of Texas Press

GRAHAM, Richard (ed.)

1992 The idea of race in Latin America, 1870-1940, Austin, University of Texas Press.

GREGORY, Steven

1998 Black Corona: race and the politics of place in an urban community, Princeton, Princeton University Press.

GROSSBERG, Lawrence

1992 We gotta get out of this place: popular convervatism and postmodern culture, London, Routledge.

GUIMARÃES, Antonio Sérgio Alfredo

1999 Racismo e anti-racismo no Brasil, São Paulo, 34.

HALL, Stuart

1980 "Encoding/Decoding", in Culture, Media, Language, London, Hutchinson, Centre for Contemporary Cultural Studies. 
João H. Costa Vargas. Apartheid brasileiro...

HALL, Stuart

1982 "The rediscovery of "ideology": return of the repressed media studies", in GUREVITCH, M.; BENNETT, T.; CURRAN, J.; WOOLLACOTT, J. (eds.), Culture, society, and the media, London, Methuen.

HANCHARD, Michael

2002 "Política transnacional negra, antiimperialismo e etnocentrismo para Pierre Bourdieu e Loic Wacquant: Exemplos de interpretacão equivocada”, Estudos Afro-Asiáticos, 24: 63-96.

HARRIS, Marvin

1956 Town and country in Brazil, New York, Columbia University Press.

HARVEY, David

1989 The condition of postmodernity: an inquiry into the origins of cultural change, Oxford, Basil Blackwell.

HASENBALG, Carlos

1979

Discriminação e desigualdades raciais no Brasil, Rio de Janeiro, Graal.

1998

"Relações raciais no contexto nacional e internacional", in Racismo, perspectivas para um estudo contextualizado da sociedade brasileira, Niterói, Editora da Universidade Federal Fluminense.

HASENBALG, Carlos \& VALLE E SILVA, Nélson do

1999 "Educação e diferenças raciais nA mobilidade ocupacional no Brasil", in HASENBALG, C.; SILVA, N. V.; LIMA, M. (eds.), Cor e estratificação social, Rio de Janeiro, Contracapa.

HENRIQUES, Ricardo

2001 Desigualdade racial no Brasil: evolução das condiçôes de vida na década de 90, Rio de Janeiro, IPEA.

HOLLOWAY, Thomas

1997

Polícia no Rio de Janeiro: repressão e resistência numa cidade do século XIX, Rio de Janeiro, Fundação Getúlio Vargas. 
Revista de Antropologia, São Paulo, USP, 2005, v. 48 No 1.

HOLSTON, James

1989

The modernist city: an anthropological critique of Brasilia, Chicago, University of Chicago Press.

HUMAN RIGHTS WATCH/AMERICAS

1997 Police brutality in urban Brazil, New York, Human Rights Watch.

HUTCHINSON, Harry

1957 Village and plantation life in northeastern Brazil, Seattle, University of Washington Press.

IANNI, Octávio

1972 Raças e classes sociais no Brasil, Rio de Janeiro, Civilização Brasileira.

INSPIR/DIEESE/AFL-CIO

1999 Mapa da população negra no mercado de trabalho, São Paulo, INSPIR (Instituto Sindical Interamericano pela Igualdade Racial).

JETER, Jon

2003

"Death squads feed terror in Rio Slums", Seattle Times, 27 october.

KAHN, Tulio

"Justiça e discriminação no Brasil", Boletim Conjuntura Criminal, 11 [www. conjunturacriminal.com.br].

2002 Velha e nova polícia: polícia e políticas de segurança pública no Brasil atual, São Paulo, Sicurezza.

KELLEY, Robin D. G.

1997 Yo Mama's disfunktional! Fighting the culture wars in America, Boston, Beacon Press.

KIM, Claire Jean

2000 Bitter fruit: the politics of black-korean conflict in New York city, New Heaven, Yale University Press.

KOWARICK, Lúcio (ed.)

1988 As lutas sociais e a cidade, Rio de Janeiro, Paz e Terra. 
João H. Costa Vargas. Apartheid brasileiro...

KOWARICK, Lúcio \& ANT, Clara

1988 "Cem anos de promiscuidade", in KOWARICK, L. (ed.), As lutas sociais e a cidade, Rio de Janeiro, Paz e Terra.

LEFEBVRE, Henri

1991 The production of space, Oxford, Blackwell Publishing.

LÉVI-STRAUSS, Claude

1986 Tristes trópicos, Lisboa, Ediçōes 70.

LIPSITZ, George

1998 The possessive investment in whiteness: how white people profit from identity politics, Philadelphia, Temple University Press.

MASSEY, Douglas \& DENTON, Nancy A.

1993 American Apartheid: segregation and the making of the underclass, Cambridge, Harvard University Press.

MENDONÇA, Maisa \& BENJAMIN, Medea

1997 Benedita, Rio de Janeiro, Mauad.

MILLER, Gerome

1996 Search and destroy: african-american males in the criminal justice system, Cambridge, Cambridge University Press.

MITCHELL, Michael \& WOOD, Charles

1998 "Ironies of citizenship: skin color, police brutality, and the challenge to democracy in Brazil”, Social Forces, 77(3): 1.001-20.

MOLLENKOPF, John

1993 New York in the 1980s: a social, economic, and political atlas, New York, Simon \& Schuster.

MOTTA, Athayde da

2003 "The culture wars of race and black NGOs in Brazil", Master's thesis, University of Texas at Austin. 
Revista de Antropologia, São Paulo, USP, 2005, v. 48 No 1.

MORNER, Magnus

1967 Race mixture in the history of Latin America, Boston, Little, Brown.

MUNANGA, Kabengele

1999 Rediscutindo a mestiçagem no Brasil: identidade nacional versus identidade negra, Petrópolis, Vozes.

NASCIMENTO, Abdias do

1968 "80 anos de abolição", Cadernos Brasileiros, 10.

1977 Racial democracy in Brazil, myth or reality? A dossier of brazilian racism, Ibadan (Nigeria), Sketch Publishing Co.

1989 Brazil: mixture or massacre?, Dover, The Majority Press.

NOGUEIRA, Oracy

1985 Tanto preto quanto branco: estudos de relaçôes raciais, São Paulo, T. A. Queiroz.

OLIVEIRA, Ney dos Santos

2002 "Direito das/dos negras/os: distribuição racial, pobreza e moradia na região metropolitana do Rio de Janeiro", Anais XXI Encontro e VI Congresso Arquisur (Salvador, Faculdade de Arquitetura, Universidade Federal da Bahia).

2001

"The location of the poor in Rio de Janeiro: the influence of race on favela", unpublished paper.

2000 "Segregação em favelas e mobilização política: um estudo comparativo de raça e classe”, Colóquio Arquitetura Brasileira: Redescobertas. XVI Congresso Brasileiro de Arquitetos, Cuiabá, 26 a 29 de set.

1999 "Cidades negras. Um estudo sobre a questão da cor nos bairros pobres da Região Metropolitana do Rio de Janeiro”, VIII Seminário de Iniciação Científica e Prêmio UFF Vasconcelos Torres de Ciência e Tecnologia da Universidade Federal Fluminense.

OLIVER, Melvin \& SHAPIRO, Thomas

1995 Black wealth/white wealth: a new perspective on racial inequality, New York, Routledge.

PERLMAN, Janice

1977 O mito da marginalidade, Rio de Janeiro, Paz e Terra. 
João H. Costa Vargas. Apartheid brasileiro...

PETRY, Sabrina

2001

"Morro carioca cria condomínio-favela", Folha de S.Paulo, 25/7.

PAIXĀO, Luiz Antonio

1995 "O problema da polícia", in Violência e Participação Política no Rio de Janeiro. Rio de Janeiro, IUPERJ, Série Estudos n. 91.

PARENTI, Christian

2000 Lockdown America: police and prison in the age of crisis, London, Verso.

RIBEIRO, Luiz Cesar de Queiroz \& TELLES, Edward E.

2000 "Rio de Janeiro: emerging dualization in a historically unequal city", in MARCUSE, Peter \& VAN KEMPEN, Ronald (eds.), Globalizing Cities, London, Basil Blackwell.

ROBINSON, William I.

1998-1999 "Latin America and global capitalism", Race \& Class, 40(2/3): 111-31.

ROLNIK, Raquel

1988 "São Paulo, início da industrialização", in KOWARICK, Lúcio (ed.), As lutas sociais e a cidade, Rio de Janeiro, Paz e Terra.

ROTHMILLER, Mike \& GOLDMAN, Ivan

1992 L. A. Secret police: inside the LAPD elite spy network, New York, Pocket Books.

SAITO, LELAND

1998 Race and politics: asian americans, latinos, and whites in a Los Angeles suburb, Urbana, University of Illinois Press.

SANTOS, Joel Rufino dos

1998 "Invisibilidade e racismo", Intercambio, 1.

SCOTT, James

1990 Domination and the art of resistance: hidden transcripts, New Heaven, CT, Yale University Press. 
Revista de Antropologia, São Paulo, USP, 2005, v. 48 no 1.

SEGATO, Rita

1998

"The color-blind subject of myth; or, where to find Africa in the nation", Annual Review of Anthropology, 27: 129-51.

SHERIFF, Robin

2001 Dreaming equality: color, race, and racism in urban Brazil, New Brunswick, NJ, Rutgers University Press.

SILVA, Denise Ferreia da

1998 "Facts of blackness: Brazil is not (quite) the United States... and racial politics in Brazil?", Social Identities, 4(2): 201-34.

SILVA, Jorge da

1998 Violência e racismo no Rio de Janeiro, Niterói, Editora da Universidade Federal Fluminense.

SILVA, Nelson do Valle \& HASENBALG, Carlos

1992 Relaçôes raciais no Brasil contemporâneo, Rio de Janeiro, Rio Fundo Editora.

SIVANANDAN, A.

2003 "Racism and the market-state: an interview", Race \& Class, 44(4): 71-76.

SOARES, Luis Eduardo

1996 Violência e política no Rio de Janeiro, Rio de Janeiro, ISER.

SUGRUE, Thomas

1996 The origins of the urban crisis: race and inequality in postwar Detroit, Princeton, Princeton University Press.

TELLES, Edward

1992 "Residential segregation by skin color in Brazil", American Sociological Review, 57(2): 186-97.

1999 "Ethnic boundaries and political mobilization among african brazilians. Comparisons with the U.S. case", in HANCHARD, M. (ed.), Racial politics in contemporary Brazil, Durham, Duke University Press.

2004 Race in another America: the significance of skin color in Brazil, Princeton, Princeton University Press. 
João H. Costa Vargas. Apartheid brasileiro...

TUAN, Yi-Fu

1977 Space and place: the perspective of experience, Minneapolis, University of Minnesota Press.

TWINE, France Winddance

1998 Racism in a racial democracy: the maintenance of white supremacy in Brazil, New Brunswick, Rutgers University Press.

VARGAS, João H. Costa

1993 "As transformações recentes de São Paulo vistas de seu epicentro", dissertação de mestrado, Campinas, Unicamp.

1999 "Blacks in the city of angels' dust", Doctoral Dissertation, University of California, San Diego.

2003 "The inner city and the favela: transnational black politics", Race \& Class, 44(4): $19-40$.

2004a "The Los Angeles times' coverage of the 1992 rebellion: still burning matters of race and justice", Ethnicities, 4(2): 209-36.

$2004 \mathrm{~b} \quad$ "Hyperconsciousness of race and its negation: the dialectic of white supremacy in Brazil", Identities, 11: 443-70.

2005 "Genocide in the african diaspora: the need for a holistic approach", Journal of Black Studies (forthcoming).

WAGLEY, Charles

1952 Amazon town: a study of man in the tropics, New York, McMillan.

WEBB, Garry

1999 Dark alliance: the CIA, the contras, and the crack cocaine explosion, New York, Seven Stories Press.

www.no.com.br

2000

Issues from 17 August 2000 - 20 august 2000.

www.starnews2001.com.br/drogas.html

2002

"Drogas: o tráfico sem fronteiras", 10 January 
Revista de Antropologia, São Paulo, USP, 2005, v. 48 No 1.

ZALUAR, Alba

A máquina e a revolta, São Paulo, Brasiliense.

1994

Condominio do diabo, Rio de Janeiro, Editora da Universidade Federal do Rio de Janeiro.

ZALUAR, Alba \& ALVITO, Marcos (eds.)

1999

Um século de favela, Rio de Janeiro, Editora Fundação Getúlio Vargas.

ABSTRACT: Based on ethnographic data collected since June 2001 in Rio de Janeiro, this article analyzes newspaper coverage of the political events that led to the installation of gates and cameras around Jacarezinho, the city's second largest favela. It draws on a literature on Brazilian cities, and suggests that closer attention must be given to how urban space and race are imposed, politicized, challenged, and transformed. In the case of Rio, such processes reveal forms of spatial segregation by race not unlike that of South Africa and the United States.

KEY-WORDS: segregation, race, favela, Rio de Janeiro, activism, transnational alliances.

Aceito em outubro de 2005. 